\title{
Do Free Mobile Apps Harm Consumers?
}

\author{
J. GREGORY SIDAK*
}

\section{TABLE OF CONTENTS}

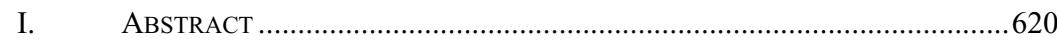

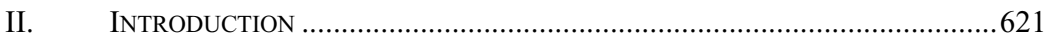

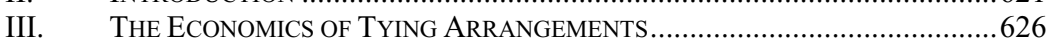

A. Tying Usually Enhances Competition .........................................627

B. Are Theoretical Models of Anticompetitive Tying Robust Enough to Justify Antitrust Intervention? ....

IV. The SuPREME COURT's Evolving JURISPRUDENCE

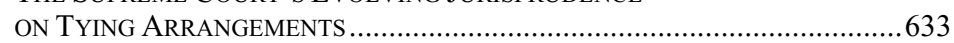

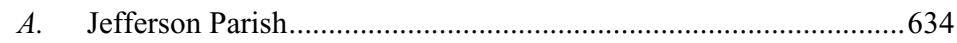

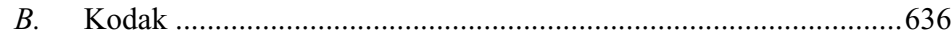

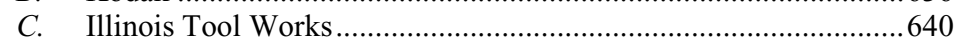

D. The Implicit Recognition of Efficiencies as an Affirmative Defense .....................................................................645

V. The D.C. CirCuit's Rule of Reason ANALysis For

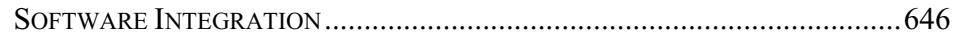

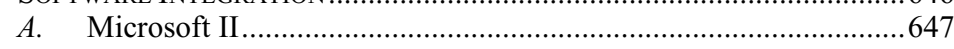

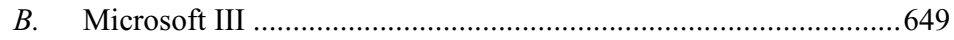

1. The District Court's Findings of Fact ....................................649

2. The D.C. Circuit's Unanimous En Banc Opinion .....................651

VI. THE MADA AND GoOGLE’s BusINESS MODEL .......................................656

A. The Android OS, Google Apps, and the Suite of

Google Mobile Services ………...................................................656

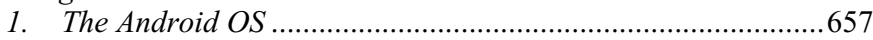

* C 2015 J. Gregory Sidak. Chairman, Criterion Economics, L.L.C., Washington, D.C. Email: jgsidak@criterioneconomics.com. Google commissioned me to write this Article in 2014, but the views I express are solely my own, and portions of this Article reprise legal and economic opinions that I first published in a 2001 article on the antitrust treatment of software integration, which Microsoft commissioned me to write during the pendency of its landmark antitrust case. 


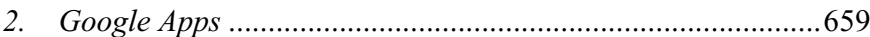

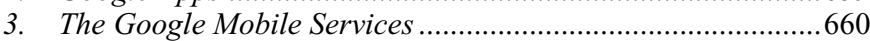

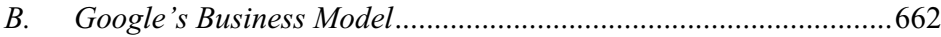

1. How Does Google Monetize Its Free Apps? ...........................662

2. Why Did Google Enter the OS Business? ...................................664

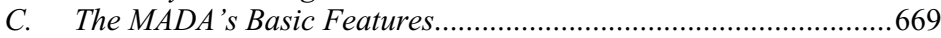

D. Google's Reasons for Offering GMS Subject to

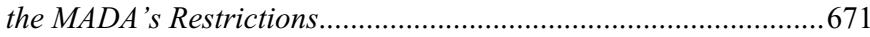

1. Countering Intra-Platform Fragmentation ............................671

2. Meeting Consumer Expectations ..............................................674

3. Avoiding Free Riding and Cherry-Picking ..........................675

VII. DO THE MADA REQUIREMENTS UNLAWFULLY

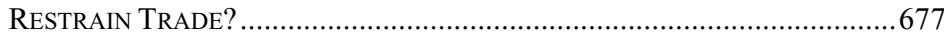

A. Allegations that the MADA's Restrictions Are Unlawful ...............677

B. The Failure of the Prima Facie Case ..............................................68 680

C. The Benefits to Consumers, Manufacturers of Mobile

Devices, and App Developers from the MADA's

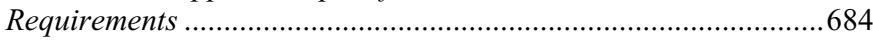

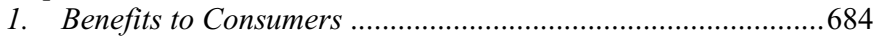

2. Benefits to Manufactures of Mobile Devices...............................686

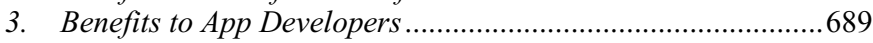

VIII. CONCLUSION

\section{ABSTRACT}

Google distributes proprietary applications for its open-source Android mobile operating system (OS) free of charge. Some of those applications (apps) are offered together as a suite of apps known as Google Mobile Services (GMS). Manufacturers of mobile devices can agree, pursuant to Google's Mobile Application Distribution Agreement (MADA), to install the suite of apps on their devices at a price of zero. Some theorize that Google's policy of offering some applications together as a suite of apps harms competitors or menaces consumer welfare. In April 2015, the European Commission expressed such concerns when it initiated a formal antitrust investigation that will scrutinize Google's licensing practice with respect to Android, mobile apps, and mobile services. In April 2014, an antitrust class-action complaint filed against Google by individual mobile device owners in the U.S. District Court for the Northern District of California presented similar allegations. However, the theory that the MADA's requirements have anticompetitive effects is wrong. As a matter of economics, Google's practice of distributing free mobile apps in the GMS suite benefits consumers - as well as manufacturers, mobile carriers, app developers, and advertisers - by stimulating demand, by reducing the risk of fragmentation of the Android OS, and by preventing Google's competitors from free riding on its investment to make the Android OS and mobile apps a viable open-source competitor to closed and proprietary-walled garden-platforms for mobile devices. As a matter of antitrust law, Google's distribution of apps as part of a larger whole - GMS - is lawful under the Supreme Court's four-part test for such arrangements. Google does not force consumers to pay for apps they do not want, and the MADA's requirements enhance competition overall. The same conclusion holds with even greater certainty under the rule-of-reason analysis for software integration that the D.C. Circuit adopted in its historic Microsoft decision. 
Although European competition law differs in some respects from American
antitrust law, the pertinent economic analysis does not vary by jurisdiction.
Google's licensing practice has invigorated competition among mobile platforms
and mobile devices. Google's distribution of free mobile apps in GMS has produced
a market success, not a market failure, and should not be considered anticompetitive.

JEL: D4; D42; K21; L11; L12; L41; L86; O34

\section{INTRODUCTION}

Google, famous for its popular search engine, entered the mobile device business with its launch of the first Android-operated mobile device in 2008. ${ }^{1}$ Android, an operating system (OS) for mobile devices, is an opensource platform available under the Apache open-source license free of charge to any end user, manufacturer of mobile devices, or developer of applications (apps). ${ }^{2}$ Google also develops mobile apps that enable users to manage various functions on their mobile devices, such as checking email, watching videos, browsing the Internet, and accessing instant chat services. $^{3}$ End users can download the vast majority of Google apps on their mobile devices free of charge. Google also permits manufacturers to preload a set of Google apps - called Google Mobile Services (GMS) on their mobile devices if they so choose. Google thereby makes its apps available to the end user "out of the box." Google offers GMS to manufacturers free of charge, provided that the manufacturer accepts the conditions specified in its Mobile Application Distribution Agreement (MADA). ${ }^{4}$

In April 2015, the European Commission formally opened an investigation into Google's licensing practices with respect to the Android mobile operating system, mobile apps, and mobile services. ${ }^{5}$ The Commission

1. Erick Tseng, The First Android-Powered Phone, Google OfFicial Blog (Sept. 23, 2008), http://googleblog.blogspot.com/2008/09/first-android-powered-phone.html [http:// perma.cc/7LAM-E9LZ].

2. See The Android Source Code, ANDROID, http://source.android.com/source/ index.html [http://perma.cc/K6PH-G3D5] (last visited Aug. 11, 2015); Licenses, ANDROID, http://source.android.com/source/licenses.html [http://perma.cc/ED82-LPL9] (last visited Aug. 11, 2015).

3. See, e.g., Google Mobile, GoOGLE, http://www.google.com/mobile/ [http://perma. cc/Y5WM-4FWF] (last visited July 15, 2015); Google Apps for Work, GoOGLE, http://www. google.com/work/apps/business/ [http://perma.cc/S9C4-57BB] (last visited Aug. 11, 2015).

4. See infra Part VI.C.

5. European Commission Press Release IP/15/4780, Antitrust: Commission Sends Statement of Objections to Google on Comparison Shopping Service; Opens Separate 
said that "Android has become the leading operating system for smart mobile devices in the [European Economic Area], to the extent that today, the majority of smartphones in Europe are based on Android." ${ }^{\circ}$ The Commission added that, although Android is an open-source operating system, "[t]he majority of smartphone and tablet manufacturers ... use the Android operating system in combination with a range of Google's proprietary applications and services." 7 The Commission further observed that "to obtain the right to install these applications and services on their Android devices, manufacturers [of mobile devices] need to enter into certain agreements with Google." ${ }^{\prime \prime}$ The antitrust investigation will evaluate whether "certain conditions in Google's agreements associated with the use of Android and Google's proprietary applications and services breach EU antitrust rules." In particular, the Commission will analyze

1. whether Google has illegally hindered the development and market access of rival mobile applications or services by requiring or incentivizing smartphone and tablet manufacturers to exclusively pre-install Google's own applications or services;

2. whether Google has prevented smartphone and tablet manufacturers who wish to install Google's applications and services ... from developing and marketing modified and potentially competing versions of Android ... on other devices, thereby illegally hindering the development and market access of rival mobile operating systems and mobile applications or services;

3. whether Google has illegally hindered the development and market access of rival applications and services by tying or bundling certain Google applications and services distributed on Android devices with other Google applications, services and/or application programming interfaces of Google. ${ }^{10}$

Formal Investigation on Android (Apr. 15, 2015), http://europa.eu/rapid/press-release_IP15-4780_en.htm [http://perma.cc/4H54-D8RV] [hereinafter Press Release, Commission Sends Statement of Objections to Google].

6. European Commission Press Release MEMO/15/4782, Antitrust: Commission Opens Formal Investigation Against Google in Relation to Android Mobile Operating System (Apr. 15, 2015), http://europa.eu/rapid/press-release_MEMO-15-4782_en.htm [http://perma.cc/3SXB-9PPM].
7. Id.
8. Id.
9. Id.
10. Id. 
Margrethe Vestager, the EU Commissioner for Competition, emphasized that the investigation will ensure that "the markets in this area can flourish without anticompetitive constraints imposed by any company." 11

The Commission's formal investigation against Google comes after private litigation in the United States raised similar theories. In April 2013, FairSearch - an association founded by Microsoft, Nokia, and several other software and Internet companies-filed a complaint with the European Commission alleging that the MADA's terms are anticompetitive. ${ }^{12}$ In April 2014, an antitrust class action complaint filed against Google by individual mobile device owners in the U.S. District Court for the Northern District of California presented similar allegations. ${ }^{13}$ The class action plaintiff filed an amended complaint on August 1, 2014. ${ }^{14}$ The amended class action complaint alleged that the MADA's requirements enable Google to "maintain and extend" its alleged monopoly in the "general search" and "handheld general search" markets. ${ }^{15}$ Judge Beth Freeman of the Northern District of California, however, dismissed the amended complaint on February 20, 2015, finding that "the allegation of antitrust injury [fell] short of the plausibility standard." "She also found that the plaintiffs' claims "fail[ed] to explain how the logical leap from that allegation to substantial market foreclosure in the market for general handheld search ... [was] reasonably based upon the existence of MADAs." 17 Though Judge Freeman left the plaintiffs the option to amend the claims

11. Press Release, Commission Sends Statement of Objections to Google, supra note 5 .

12. FairSearch Announces Complaint in EU on Google's Anti-Competitive Mobile Strategy, FAIRSEARCH (Apr. 9, 2013), http://www.fairsearch.org/mobile/fairsearch-announcescomplaint-in-eu-on-googles-anti-competitive-mobile-strategy/ [http://perma.cc/HTH7A9ZM]; see also Foo Yun Chee \& Alexi Oreskovic, European Regulators Training Sights on Google's Mobile Software, REUTERS (July 30, 2014, 5:15 PM), http://www.reuters. com/article/2014/07/30/us-google-europe-android-insight-idUSKBN0FZ2B220140730 [http://perma.cc/ES3Y-UN6B] ("European regulators are laying the groundwork for a case centered on whether Google abuses the 80 percent market share of its Android mobile operating system to promote services from maps to search.”).

13. Class Action Complaint, Feitelson v. Google Inc., No. 5:14-cv-02007-HRL (N.D. Cal. May 1, 2014), 2014 WL 1715185 [hereinafter Class Action Complaint].

14. First Amended Class Action Complaint, Feitelson v. Google Inc., No. 5:14-cv02007-BLF (N.D. Cal. Aug. 1, 2014), 2014 WL 3971376 [hereinafter First Amended Class Action Complaint].

15. Id. at 4 .

16. Order Granting Motion to Dismiss First Amended Complaint With Leave to Amend at 12, Feitelson v. Google Inc., No. 5:14-cv-02007-BLF (N.D. Cal. Feb. 20, 2015).

17. Id. at 15 . 
and present more plausible allegations about the anticompetitive effects of Google's licensing practice to the court, ${ }^{18}$ the plaintiffs voluntarily dismissed the case on April 3, 2015. ${ }^{19}$

In this Article, I examine the economic implications that the MADA has on the concerned markets and ultimately on consumers. I show that Google's licensing practices increase consumer welfare and therefore should not raise anticompetitive concerns.

In Part III of this Article, I review the economic literature on potential tying arrangements. Most economists recognize that tying usually increases competition and benefits consumers by reducing costs or improving quality control. ${ }^{20}$ Although some theorists describe models in which tying might have harmful effects, economists generally caution, first, that courts will find these models to have little practical value in antitrust inquiries and, second, that the effects of alleged tying be assessed factually on a case-by-case basis. ${ }^{21}$ Put differently, tying practices rarely have anticompetitive effects. In Part IV, I analyze the development of the U.S. Supreme Court's evolving antitrust jurisprudence on tying arrangements. Although the Court continues to label some tying arrangements as per se illegal, in fact the Court applies a rule of reason analysis that requires an analysis of foreclosure effects and includes an affirmative defense of efficiency justifications. In Part V, I examine the explicit rule of reason standard for software integration used by the U.S. Court of Appeals for the D.C. Circuit. I identify the elements that one needs to prove to show that a tying practice constitutes anticompetitive behavior.

In Part VI, I explain the relevance of the MADA's requirements to Google's business model. I first analyze the relationship between the Android OS, Google apps, and GMS. Although the use of these products is interrelated, Google does not precondition the use of one product on the use of another. In particular, a manufacturer using the Android OS on its devices is not forced to preload GMS. The manufacturer may offer its devices without any Google apps. ${ }^{22}$ In fact, Amazon has decided to offer a set of smartphones and tablets that operate on Android but do not have GMS preloaded. ${ }^{23}$ In addition, manufacturers that preload GMS are free

18. Id. at 19

19. Plaintiffs' Notice of Voluntary Dismissal, Feitelson v. Google Inc., No. 5:14cv-02007-BLF (N.D. Cal. Apr. 3, 2015) [hereinafter Plaintiffs' Notice of Voluntary Dismissal].

20. See infra Part III.

21. See infra Part III.

22. See infra Part VI.

23. See Peter Burrows, Amazon Fire Takes Android, Leaves Google Apps Behind BLOOMBERG (Jan. 24, 2012), http://www.bloomberg.com/news/2012-01-24/amazon-firetakes-android-while-leaving-google-apps-behind-tech.html [http://perma.cc/S7HT-T8DK]. 
to - and in fact often do-preload on their mobile devices non-Google apps as well. I next show how the MADA's features serve Google's business model. By providing an open mobile platform, Android facilitates Google's participation in the mobile device business. Android and GMS are free, which increases Google's audience of end users. Google's role in developing Android as a trusted open platform was important to Google's successful entry into mobile markets. The MADA addresses the risk that Android will fragment into incompatible versions - a particularly severe risk for open operating systems, such as Android. ${ }^{24}$ The MADA's requirements enable Android-operated devices that include GMS to meet consumer expectations, by offering an out of the box experience comparable to that offered by mobile devices that rely on closed or propriety operating systems. The MADA's requirements also enable Google to avoid free riding and cherry-picking by its competitors, which would harm Google's ability to fund continued investments in innovation for mobile devices and applications. Therefore, Google has compelling business justifications for the MADA's licensing requirements.

In Part VII, I examine the antitrust allegations that the MADA's requirements enable Google to restrict competition from other developers' apps, restrict manufacturers' choice of apps, and protect Google's alleged monopoly over general search. Those allegations are unpersuasive as a factual matter, as an economic matter, and ultimately as a legal matter. Under U.S. antitrust law, the allegations presented against Google cannot support the prima facie case for unlawful tying under the Supreme Court's current jurisprudence. A court should well consider the apps distributed as a suite in GMS to be a single product, not two (or more) distinct products. There is no evidence that Google has market power over any service in the app suite. Hence, Google cannot meaningfully force any consumers to pay for a product that they do not want. In short, the MADA requirements harm neither consumers nor competition.

One reaches the same conclusion when analyzing the economic impact of the MADA's requirements under the D.C. Circuit's rule of reason approach to software integration. Google's strategy of distributing free apps for Android is lawful and benefits consumers. By making GMS

24. See, e.g., Neil McAllister, Google to Devs: Fragmenting Android Is Against the Rules, REGISTER (Nov. 15, 2012, 9:08 PM), http://www.theregister.co.uk/2012/11/15/ android_sdk_fragmentation_license_change/[http://perma.cc/6NZV-6KKT] (emphasizing Android's vulnerability to fragmentation). 
available out of the box and free of charge, the MADA directly benefits consumers. The MADA's requirements also benefit manufacturers of mobile devices. The ability to obtain both the OS and GMS free of charge enables a manufacturer to compete effectively with vertically integrated mobile device manufacturers without developing its own OS, mobile suite, or both. Furthermore, by sustaining Android's appeal, the MADA's requirements enable Google to compete with other OS providers in attracting app developers. Therefore, the MADA not only benefits consumers, but also creates significant positive externalities that benefit other stakeholders in the mobile industry.

Although EU competition rules on tying practices may differ from U.S. antitrust rules, the conclusions drawn from proper economic analysis do not. Economic analysis of Google's licensing practice shows that the MADA's requirements promote Android's competitiveness in the market for mobile platforms. ${ }^{25}$ Android's competitiveness benefits not only Google and its consumers, but also other stakeholders in the mobile-device industry, such as manufactures of mobile devices and app developers. By keeping the market for mobile operating systems competitive, the MADA's requirements thus benefit consumers both directly and indirectly.

\section{THE ECONOMICS OF TYING ARRANGEMENTS}

A "tie-in" or "tying" refers to a seller's offer to sell one product (the tying product) only if the buyer will purchase from that seller another product (the tied product). ${ }^{26}$ A tying arrangement can be a bundled tie (for example, the sale of a pair of shoelaces), a contractual tie (for example, contractually mandating the purchase of insurance from a particular company with a car rental), or a technological tie (for example, the functional integration of a music app with a computer's OS). ${ }^{27}$ Although some economists have theorized that tying or bundling might be anticompetitive, the dominant view within economic theory is that tying usually is procompetitive and enhances consumer welfare.

25. See infra Part VII.C.

26. See N. Pac. Ry. Co. v. United States, 356 U.S. 1, 5-6 (1958).

27. See U.S. Dep'T OF Justice, COMPetition and Monopoly: Single-Firm CONDUCT UNDER SECTION 2 OF THE SHERMAN ACT 78 (2008), http://www.justice. gov/atr/public/reports/236681.pdf [http://perma.cc/SXE9-Z3HQ] (defining different types of tying arrangements); see also J. Gregory Sidak, Debunking Predatory Innovation, 83 COLUM. L. REV. 1121 (1983) (providing an early analysis of technological tie-ins). 


\section{A. Tying Usually Enhances Competition}

Economists have described numerous examples when a tying practice serves a procompetitive purpose. ${ }^{28}$ Tying can enable economies of joint sales, and thereby reduce costs and lower prices to consumers. When the cost of offering a choice is high (for example, as with the labor and distribution costs of configuring an entirely different array of options for each buyer of a new car), a producer may bundle product features to reduce costs by offering options only in a limited range of bundles. Bundling in such cases can improve welfare. ${ }^{29}$

When buyers have diverse preferences, tying multiple goods in one package increases overall output and social welfare. ${ }^{30}$ Suppose buyer $A$ values product $X$ at $\$ 50$ and product $Y$ at $\$ 20$, and buyer $B$ values product $X$ at $\$ 20$ and product $Y$ at $\$ 50$. If the seller does not bundle the products, he will sell both products at $\$ 50$ each. The seller will receive $\$ 100$, and both buyers will obtain only one product each. To sell both products to both of the buyers, the seller would need to set the price at $\$ 20$, which would yield revenue of only $\$ 80$. On the other hand, the seller can sell a bundle containing both goods at $\$ 70$. In that case, the seller will receive $\$ 140$, and both buyers will obtain two products. This example does not depend on the seller having market power over either product $X$ or product $Y$. Bundling of software features is common in competitive markets. For example, office suites-like Microsoft Office-typically bundle the spreadsheet with the text editor to enable the user to create both graphs and text documents. Software makers have a strong incentive to bundle complementary software products to increase demand. ${ }^{31}$

Bundling products may also decrease the cost of manufacturing products for a wider range of consumers. ${ }^{32}$ Consider the myriad sections contained

28. See Alden F. Abbott \& Joshua D. Wright, Antitrust Analysis of Tying Arrangements and Exclusive Dealing, in 4 ENCYCLOPEDIA OF LAW AND ECONOMICS: ANTITRUST LAW AND ECONOMICs 183, 189-90 (Keith N. Hylton ed., 2d ed. 2010).

29. See David S. Evans \& Michael Salinger, Why Do Firms Bundle and Tie? Evidence from Competitive Markets and Implications for Tying Law, 22 YALE J. ON REG. 37, 70-71 (2005).

30. See J. Gregory Sidak, An Antitrust Rule for Software Integration, 18 YALE J. ON REG. 1, 15-17 (2001); see also Direct Testimony of Professor Richard L. Schmalensee on behalf of Microsoft Corp. para. 241, United States v. Microsoft Corp., No. 98-1232 (D.D.C. 1999) (applying this rationale to bundling of web browsers and operating systems).

31. Sidak, supra note 30, at 17.

32. See Evans \& Salinger, supra note 29 , at 52-53. 
in the Sunday New York Times. The marginal cost to the newspaper of providing the book review section to someone interested only in the sports section is zero. That condition holds regardless of the fact that the New York Review of Books can exist as a freestanding (unbundled) substitute for the New York Times Book Review. Indeed, the marginal cost to the New York Times of stripping the New York Times Book Review from the newspaper going to subscribers who read only the sports section would be astronomical. If priced on an avoided-cost basis, the stripped-down Sunday New York Times would cost more than the fully integrated newspaper. ${ }^{33}$

Bundling often increases demand for the bundled products. ${ }^{34}$ Increased demand results from product integration if there is superadditivity of demand across two outputs, $A$ and $B$, when they are produced as an integrated product. The increased demand may result because the product definition has changed as a result of the integration in a manner that produces more satisfaction (utility) for consumers. Otherwise, bundling may result because the integration of $A$ and $B$ reduces the cost to the consumer of engaging in product assembly or integration on her own. Or, the increased demand may result from some factor that is impossible to predict a priori, but is reflected, ultimately and objectively, in consumers' higher willingness to pay.

Lower costs result from product integration if there is subadditivity of costs across two outputs, $A$ and $B$. This efficiency will unambiguously benefit consumers, because even a monopolist's profit-maximizing price will fall in the face of declining costs. ${ }^{35}$ Subadditivity of costs is present if a firm with a given cost function "has lower costs than would an allocation of output among two or more firms using the same cost function." words, it is more efficient for the single firm to produce $A$ and $B$ as an integrated product than it is for the firm (or multiple firms) to produce $A$ separately from $B .^{37}$ Such efficiencies are also known as economies of scope. ${ }^{38}$ "The firm's technology is said to exhibit economies of scope when it is less costly for one firm to produce a set of goods jointly than for distinct firms to produce individual goods or subsets of goods separately." 39

33. See Massimo Motta, Competition Policy: Theory And Practice 460 (2004).

34. See Evans \& Salinger, supra note 29, at 63.

35. J. Gregory SidaK \& DANiEl F. SpUlber, Deregulatory Takings and the Regulatory CONTRACT: THE COMPETITIVE TRANSFORMATION OF NETWORK INDUSTRIES IN THE UNITED STATES 20 (1997).

36. Id.

37. Id.

38. Id. at 22 .

39. Id. "[A]lthough natural monopoly implies economies of scope, the converse is not the case. Most multiproduct firms derive economies of scope from joint production; 
The analysis of cost subadditivity also implicitly answers the question of who-the producer or the consumer - is the more efficient integrator of individual functionalities. Although it may be feasible for the consumer to integrate separate functionalities, the consumer may not be the lowest-cost integrator. The superior efficiency of the producer is a factual question whose answer depends on economies of scale and scope as well as learning-by-doing effects that allow the producer's unit cost of product integration to fall over time, with its level of cumulative output. In the case of a mobile device, the producer in this sense collectively consists of the provider of the mobile OS and apps, the manufacturer, and the mobile network operator.

Further, tying products also often improves the user experience. ${ }^{40}$ Tying can enable a firm "to ensure proper performance of a product system." 41 Quality control is especially important for complex goods like software. Consumers might have a limited understanding of how such complex systems work and might use inferior or incompatible components. ${ }^{42}$ Consumers might consequently blame one firm for a failure caused by the deficiencies of another firm's product. ${ }^{43}$ When tying performs a quality control function, it clearly enhances consumer welfare. ${ }^{44}$

\section{B. Are Theoretical Models of Anticompetitive Tying Robust Enough to Justify Antitrust Intervention?}

Economists and legal scholars associated with the Chicago School of antitrust analysis disputed the early view that a monopolist could use tying and bundling to leverage its market power in one market into a second market and charge supracompetitive prices in the second market. ${ }^{45}$

it is a primary motivation for companies to diversify their product offerings. That achievement of economies of scope does not imply that those companies could serve their entire markets at lower cost than two or more firms." Id.

40. See Robert O’Donoghue \& A. Jorge Padilla, The Law and Economics of ARTICLE 82 EC, at 482 (2006).

41. See Sidak, supra note 27, at 1136.

42. See Sidak, supra note 30 , at 9 .

43. Id.

44. See MotTA, supra note 33, at 461 (explaining that tying different components together might be "an efficient response to asymmetric information" and can enable the seller to ensure that "consumers enjoy the highest possible quality of the products they buy").

45. See 3A Phillip E. Areeda \& Herbert Hovenkamp, Antitrust law: An ANAlysis of ANTITRUst PRINCIPLES AND TheIR APPLICATION \ 758b (2d ed. 2002); 
Herbert Hovenkamp - not considered a Chicago School antitrust scholar - has succinctly summarized this key insight: "[I]n any multi-stage distribution chain there is but a single monopoly profit to be earned." 46 This "single monopoly profit theorem" demonstrates that a monopolist selling two complementary goods can earn a monopoly profit only in the market for one of those goods - either that of the tying product or the tied product. ${ }^{47}$ Therefore, the monopolist cannot increase its total profit by monopolizing a market for a complementary product if that market is competitive. Nobel laureate George Stigler presented a simple example: if product $A$ is worth $\$ 100$ to a consumer and product $B$ is worth nothing, by tying $B$ to $A$, the manufacturer will not be able to charge the consumer more than $\$ 100 .^{48}$ Chicago School economists and legal scholars thus argued that anticompetitive purposes rarely motivate tying agreements. To the contrary, tying agreements typically exist to reduce costs or implement price discrimination. ${ }^{49}$

Despite recognizing the typically procompetitive effects of tying, some economists and legal scholars - often identified with the "Post-Chicago School" of antitrust economics - argued that the Chicago School overstated the case that tying is not anticompetitive. For example, Einer Elhauge asserts that the single monopoly profit theorem holds only when the following conditions are met: (1) the tying product and the tied product are consumed in fixed proportion, (2) the demand for the two products are highly correlated, (3) the tying product is consumed at fixed levels, (4) the competitiveness of the market for the tying product is fixed, and (5) the competitiveness of the market for the tied product is fixed. ${ }^{50}$ Elhauge argues that, when those conditions are relaxed, the single monopoly profit theorem is wrong - that is, that tying can have anticompetitive effects. ${ }^{51}$ He maintains that tying can enable the monopolist to price-discriminate

Robert H. Bork, The Antitrust Paradox: A Policy at War with Itself 372-75 (1993); Ward S. Bowman, Jr., Tying Arrangements and the Leverage Problem, 67 YALE L.J. 19 (1957); Aaron Director \& Edward H. Levi, Law and the Future: Trade Regulation, 51 Nw. U. L. Rev. 281, 290 (1956); Richard A. Posner, The Chicago School of Antitrust Analysis, 127 U. PA. L. REV. 925, 927-28 (1979).

46. Herbert Hovenkamp, Post-Sale Restraints and Competitive Harm: The First Sale Doctrine in Perspective, 66 N.Y.U. ANN. SuRV. AM. L. 487, 515 (2011).

47. Robert H. Bork, The ANTITRUst PARAdOX 372-75 (1993).

48. George J. Stigler, United States v. Loew's Inc.: A Note on Block-Booking, 1963 SuP. CT. ReV. 152, 152-53. The late Judge Bork and I discussed the implications of the single-monopoly-profit theorem for antitrust analysis of Google's business in Robert $\mathrm{H}$. Bork \& J. Gregory Sidak, What Does the Chicago School Teach About Internet Search and the Antitrust Treatment of Google?, 8 J. COMPETITION L. \& ECON. 663, 674-77 (2012).

49. See BorK, supra note 47, at 375-81.

50. Einer Elhauge, Tying, Bundled Discounts, and the Death of the Single Monopoly Profit Theory, 123 HARV. L. REV. 397, 400 (2009).

51. Id. at 404 . 
among buyers of the tying product if buyers consume the tied product in varying amounts. ${ }^{52}$ Further, Elhauge maintains that tying can allow the monopolist to price discriminate among buyers of both the tying and the tied products if the demand for the tying product and that for the tied product are not highly correlated. ${ }^{53}$ According to Elhauge, tying may thus allow the monopolist to extract the consumer surplus of each individual buyer. ${ }^{54}$ Finally, Elhauge suggests that tying can increase market power in the tied product or in the tying product markets. For example, he suggests that by foreclosing the tied market and thereby hindering entry into the tying market by firms in the tied market, a firm can preserve its market power in the tying market. ${ }^{55}$

Antitrust scholars have exposed several flaws in Elhauge's criticism of the single-monopoly-profit theorem. ${ }^{56}$ First, they observe that Elhauge's criticism contradicts the available empirical evidence. ${ }^{57}$ Several empirical studies have shown that tying arrangements more often increase consumer welfare than harm consumers. ${ }^{58}$ Hence, Elhauge's statement that tying will generally serve an anticompetitive purpose finds no empirical support. Second, Elhauge's analysis is artificially narrow, as he disputes only the horizontal application of the single monopoly profit theorem and ignores its vertical application..$^{59}$ Finally, Elhauge's conclusion that tying is generally anticompetitive rests on a restrictive array of factual scenarios regarding metering ties, bundling, or imperfect price discrimination. ${ }^{60}$ For example, Elhauge assumes that: (1) demand for the monopoly good and

52. Id.

53. Id. at 405 . "Without strong positive demand correlation, tying can profitably permit price discrimination across buyers of both products." Id. at 400 .

54. Id. at 400 ("If buyers purchase varying amounts of the tying product, tying can profitably extract consumer surplus from individual buyers.").

55. Id. at 413. "Without fixed tying market competitiveness, tying can increase the degree of tying market power." Id. at 400.

56. See Paul Seabright, Group Commentary on Tying, Bundled Discounts, and the Death of the Single Monopoly Profit Theory by Einer Elhauge: The Undead? A Comment on Professor Elhauge's Paper, 5 COMPETITION POL'Y INT'L 243 (2009); see also Daniel A. Crane \& Joshua D. Wright, Commentary, Can Bundled Discounting Increase Consumer Prices Without Excluding Rivals?, 5 COMPETITION POL'Y INT'L 209 (2009).

57. Seabright, supra note 56, at 243-44, 246-47.

58. See id. at 244; Crane \& Wright, supra note 56, at 210 (citing Bruce H. Kobayashi, Does Economics Provide a Reliable Guide to Regulating Commodity Bundling By Firms? A Survey of the Economic Literature, 1 J. COMPETITION L. \& ECON. 707 (2005)); Evans \& Salinger, supra note 29.

59. See, e.g., Bork \& Sidak, supra note 48, at 675-77, 676 n.44.

60. Id. at 676 n. 44 . 
the competitive good are independent, and (2) the tying must coerce the buyer of the monopoly good to purchase all future quantities of the competitive good at monopoly prices. However, as Paul Seabright observes, except "in wildly implausible circumstances," these two conditions are extremely unlikely ever to be met simultaneously. ${ }^{61}$

Similarly, Michael Whinston theorized that the Chicago School critique of leveraging applies only when the tied market is perfectly competitive. ${ }^{62}$ In his model, tying commits the monopolist to being more aggressive than the entrant, and that commitment discourages entry. Whinston shows that tying could be used to deter entry into, and thereby to monopolize, the tied product market if (1) the selling firm is a monopolist in the tying product market, (2) the tied-product market has decreasing average costs over the relevant range of output, and (3) the tied and tying products are used in variable proportions. ${ }^{63}$ Whinston finds, however, that the predicted welfare effects of even that specialized case of tying are ambiguous. ${ }^{64}$

In sum, theories of the anticompetitive effects of tying rest on numerous assumptions that are either unrealistic or impossible to prove as a factual matter in litigation. As Judge Frank Easterbrook has said, "The development of complex models is one thing, proof of their utility is another." ${ }^{\circ 5}$ Even the authors of theoretical models of anticompetitive tying concede that their analysis does not "justify intervention on antitrust grounds." 66 To the contrary, they emphasize that attempting to eliminate inefficiency by means of antitrust intervention is "fraught with the usual difficulties of figuring out when to intervene and interfering with the functioning of markets." ${ }^{, 67}$ Application of tying theories that rest on complex assumptions would lead to an increased error rate in the courts. These errors would deter efficient behavior and distort dynamic competition. ${ }^{68}$

As a result, economists generally advocate a cautious approach to scrutinizing tying agreements under antitrust law. They emphasize that a rule of per se illegality is not justified and that tying agreements should be

61. Seabright, supra note 56, at 248 .

62. Michael D. Whinston, Tying, Foreclosure, and Exclusion, 80 AM. Econ. Rev. 837, 838-39 (1990).

63. See id. at $846,850,854$.

64. Id. at $855-56$.

65. Frank H. Easterbrook, Correspondence, Workable Antitrust Policy, 84 MicH. L. REV. 1696, 1709 (1986).

66. Dennis W. Carlton, Joshua S. Gans \& Michael Waldman, Why Tie a Product Consumers Do Not Use?, AM. Econ. J.: MicroeconOMICS, Aug. 2010, at 85, 102.

67. Id.

68. See Robert H. Bork \& J. Gregory Sidak, The Misuse of Profit Margins To Infer Market Power, 9 J. COMPETITION L. \& ECON. 511, 524-26 (2013) (quoting Frank H. Easterbrook, The Limits of Antitrust, 63 TEX. L. REV. 1, 2 (1984)). 
evaluated on a case-by-case basis. ${ }^{69}$ Massimo Motta, the current chief economist of the Directorate General for Competition of the European Commission, explains that, "[i]n most cases, tying will have efficiency effects that will benefit consumers .... [However,] in a few (probably rare) cases, it might have harmful exclusionary effects that should be balanced with any possible efficiency effects." 70 As a result, in Motta's view, a full investigation is necessary to weigh the potential negative effects with the efficiency justifications behind the tying practice. ${ }^{71}$ In particular, scholars emphasize that a theoretical demonstration of harm does not suffice to establish that the scrutinized practice actually harms consumers. ${ }^{72}$ It is necessary to evaluate whether such harm has arisen in practice.

\section{THE SUPREME COURT's EVOLVING JURISPRUDENCE ON TYING ARRANGEMENTS}

In 2006, the Supreme Court in Illinois Tool Works Inc. v. Independent Ink, Inc. ${ }^{73}$ abandoned the presumption, announced in 1949 in Standard Oil of California $v$. United States, that tying agreements "serve hardly any other purpose beyond the suppression of competition." "74 Even before 2006, the Court had indicated its declining support for the older proposition that tying should be per se illegal by ruling that a tying arrangement is unlawful only if four elements are met: (1) there are two separate products or services, (2) the sale of one product or service (the tying product) is conditioned upon the purchase of another product (the tied product), (3) the seller possesses market power in the tying product market, and (4) the tie-in forecloses a substantial amount of the commerce in the tied product

69. See, e.g., Jean Tirole, The Analysis of Tying Cases: A Primer, 1 COMPETITION POL'y INT'L 1, 25 (2005); MotTA, supra note 33, at 463; Evans \& Salinger, supra note 29 , at 42 .

70. MotTA, supra note 33, at 467.

71. Id.

72. Dennis W. Carlton \& Michael Waldman, The Strategic Use of Tying To Preserve and Create Market Power in Evolving Industries, 33 RAND J. ECON. 194, 215 (2002) ("[T]rying to turn the theoretical possibility for harm shown here into a prescriptive theory of antitrust enforcement is a difficult task.").

73. Ill. Tool Works Inc. v. Indep. Ink, Inc., 547 U.S. 28, 35, 36 (2006) (quoting Standard Oil Co. v. United States, 337 U.S. 293, 305-06 (1949)).

74. Standard Oil Co., 337 U.S. at 305-06. 
market. ${ }^{75}$ Various lower courts ${ }^{76}$ have interpreted this fourth element to require proof of an anticompetitive effect in the tied market comparable to the "dangerous probability of achieving monopoly power" that the Court requires for the prima facie case for attempted monopolization under section 2 of the Sherman Act. ${ }^{77}$ Only when all four elements are met will the Court consider a tying practice anticompetitive. Even if those four conditions are present, fact-based evidence of economic efficiencies can overcome a finding of per se illegality. ${ }^{78}$ In particular, the evaluation of market power depends not on evidentiary presumptions, but on economic evidence. ${ }^{79}$ Accordingly, the Court's antitrust scrutiny of tying arrangements has evolved from a per se analysis to what is instead a de facto rule of reason analysis.

\section{A. Jefferson Parish}

In Jefferson Parish Hospital District No. 2 v. Hyde, the Court in 1984 examined an agreement by which a hospital required its patients to procure anesthesiology services from only one firm of anesthesiologists. ${ }^{80}$ In an opinion by Justice Stevens, the Court said that, although it was "far too late in the history of our antitrust jurisprudence to question the proposition that certain tying arrangements pose an unacceptable risk of

75. See Eastman Kodak Co. v. Image Tech. Servs., Inc., 504 U.S. 451, 462 (1992).

76. See, e.g., Technical Res. Servs., Inc. v. Dornier Med. Sys., Inc., 134 F.3d 1458, 1466, 1468 (11th Cir. 1998); Carl Sandburg Vill. Condo. Ass'n No. 1 v. First Condo. Dev. Co., 758 F.2d 203, 210-11 (7th Cir. 1985); Will v. Comprehensive Accounting Corp., 776 F.2d 665, 671 (7th Cir. 1985).

77. See, e.g., Spectrum Sports, Inc. v. McQuillan, 506 U.S. 447, 455-56 (1993).

78. See Eastman Kodak Co., 504 U.S. at 486; see also Mozart Co. v. MercedesBenz of N. Am., Inc., 833 F.2d 1342, 1351 (9th Cir. 1987) (permitting a business justification defense of quality assurance and goodwill for a tied-in product); Johnson v. Nationwide Indus., Inc., 715 F.2d 1233, 1237 (7th Cir. 1983) (permitting the tying of a management contract to the sales of condominiums); Dehydrating Process Co. v. A. O. Smith Corp., 292 F.2d 653, 655-56 (1st Cir. 1961) (permitting the seller of silos to tie silo unloaders where many silo customers using unloaders of other manufacturers complained of problems).

79. Extending this reasoning, the analysis of market power should not focus simply on the defendant firm's market share. Rather, the analysis of market power must consider the firm's market share together with other relevant factors - including the price elasticities of demand and of supply - while discounting ambiguous evidence such as profit margins. See Bork \& Sidak, supra note 68, at 530 (explaining why courts should be skeptical of using profit margins to infer market power); Franklin M. Fisher \& John J. McGowan, On the Misuse of Accounting Rates of Return to Infer Monopoly Profits, 73 AM. ECON. ReV. 82 (1983); William M. Landes \& Richard A. Posner, Market Power in Antitrust Cases, 94 HARV. L. REV. 937, 983 (1981) (describing method to estimate the price elasticity of demand (for the market and for the defendant firm) and the price elasticity of supply to assess market power rigorously).

80. Jefferson Par. Hosp. Dist. No. 2 v. Hyde, 466 U.S. 2, 6 (1984). 
stifling competition and therefore are unreasonable "per se," it was nonetheless the case that "not every refusal to sell two products separately can be said to restrain competition." distinguished by "the essential characteristic of ... forc[ing] the buyer into the purchase of a tied product that the buyer either did not want at all, or might have preferred to purchase elsewhere on different terms." contrast, tying arrangements used to maximize a seller's return on the tying product were not subject to per se condemnation, for they were not necessarily coercive or anticompetitive. ${ }^{83}$

No Justice dissented. In that sense, Jefferson Parish might seem a simple case. However, the concurring opinions reveal that the real debate between the Justices concerned the continued wisdom of a per se rule. ${ }^{84}$ In her concurring opinion, Justice O'Connor (joined by Chief Justice Burger and Justices Rehnquist and Powell) criticized the per se rule for requiring a court to conduct a fact-intensive inquiry into the real-world economic effects of a tie-in while denying the court the ability to permit the tie-in if the evidence showed it to be beneficial. ${ }^{85}$ Justice O'Connor's approach would evaluate tying arrangements according to the rule of reason, which would invalidate such arrangements only in the "rare cases where power in the market for the tying product is used to create additional market power in the market for the tied product." ${ }^{\text {" }}$ A plaintiff would need to meet a higher evidentiary threshold for a court to invalidate a tie-in per se-proving that the seller had market power in the tyingproduct market, ${ }^{87}$ that there existed a "substantial threat that the tying seller will acquire market power in the tied-product market," there existed a "coherent economic basis for treating the tying and tied products as distinct." 89 Finally, even if the plaintiff made such a showing, a tie-in still would be permitted if its economic benefits exceeded its

81. Id. at 9,11 .

82. Id. at 12 .

83. Id. at 14

84. Compare id. at 32 (Brennan, J., concurring) (endorsing the per se rule), with id. at 32-47 (O'Connor, J., concurring) (opposing the per se rule in favor of an analysis of tie-ins under the rule of reason).

85. Id. at 34 (O'Connor, J., concurring).

86. Id. at 36 .

87. Id. at 37

88. Id. at 38

89. Id. at 39 
harms. ${ }^{90}$ As mentioned above, various lower courts have in fact followed Justice O'Connor's approach by interpreting the fourth element for unlawful tying to require proof of an anticompetitive effect in the tied market that resembles the proof of a "dangerous probability of achieving monopoly power" that the Court considers under section 2 of the Sherman Act, ${ }^{91}$ and by accepting fact-based evidence of economic efficiencies to preclude a finding of per se illegality. ${ }^{92}$

One important point of disagreement between the majority opinion and the concurring opinions in Jefferson Parish was the question of how to determine whether the tying arrangement involved two products or only one. According to the majority, "the answer to the question whether one or two products are involved turns not on the functional relation between them, but rather on the character of the demand for the two items." ${ }^{\prime 93}$ Under the majority's approach, two products are deemed to exist if sufficient demand exists to create distinct and separate markets for both the tying and the tied products. ${ }^{94}$ Justice O'Connor rejected this reasoning. She (and the three other concurring Justices) thought it was absurd to apply the majority's analysis to integrated products:

\begin{abstract}
All but the simplest products can be broken down into two or more components that are "tied together" in the final sale. Unless it is to be illegal to sell cars with engines or cameras with lenses, this analysis must be guided by some limiting principle.... Even when the tied product does have a use separate from the tying product, it makes little sense to label a package as two products without also considering the economic justifications for the sale of the package as a unit. When the economic advantages of joint packaging are substantial the package is not appropriately viewed as two products, and that should be the end of the tying inquiry. ${ }^{95}$
\end{abstract}

Eight years later, in 1992, the Court would revisit this issue of how to determine whether an alleged tie-in involves two products or one.

\title{
B. Kodak
}

Eastman Kodak Co. v. Image Technical Services, Inc. concerned Kodak's practice of tying replacement parts to the purchase of repair services for

90. Id. at 41

91. See supra note 76 and accompanying text.

92. See Eastman Kodak Co. v. Image Tech. Servs., Inc., 504 U.S. 451, 486 (1992); see also Dehydrating Process Co. v. A. O. Smith Corp., 292 F.2d 653, 655-56 (1st Cir. 1961); Johnson v. Nationwide Indus., Inc., 715 F.2d 1233, 1237 (7th Cir. 1983); Mozart Co. v. Mercedes-Benz of N. Am., Inc., 833 F.2d 1342, 1351 (9th Cir. 1987)
93. Jefferson Par., 466 U.S. at 19.
94. Id. at $21-22$
95. Id. at 39-40 (O'Connor, J., concurring). 
Kodak photocopiers. ${ }^{96}$ The Court considered whether, for purposes of tying law, replacement parts and repair service for Kodak photocopiers were separate products. ${ }^{97}$ Justice Blackmun's opinion for the Court found that parts and service were distinct markets and rejected Kodak's claim that, even if the company held a monopoly over replacement parts for Kodak photocopiers, interbrand competition among photocopier manufacturers prevented Kodak from exploiting that market power. ${ }^{98}$

Notwithstanding the reasoning of Justice O'Connor's concurrence on behalf of four Justices in Jefferson Parish, the Court in Kodak first found that parts and service could plausibly be considered separate products because there was "sufficient consumer demand so that it [would be] efficient for a firm to provide service separately from parts." the argument that parts and service could not constitute distinct markets because no demand existed for parts separately from service: "By that logic, we would be forced to conclude that there can never be separate markets, for example, for cameras and film, computers and software, or automobiles and tires." ${ }^{100}$ Kodak, the Court observed, sold service with parts to some, service without parts to others, and parts without service to yet other consumers. ${ }^{101}$

In a dissent joined by Justices O'Connor and Thomas, Justice Scaliawho, like Justice Thomas, had joined the Court since it had decided Jefferson Parish - criticized the majority's reliance on "sufficient consumer demand" to find that replacement parts and repair service constituted distinct markets. ${ }^{102}$ He found that not only was the repair service that Kodak provided "inherently associated with the parts," but that customers tended to demand the two items in fixed proportions, buying "one part with one unit of service necessary to install the part." ${ }^{103}$ Quoting the antitrust casebook by Phillip Areeda and Louis Kaplow, which in turn quoted Ward Bowman's influential 1957 article on the economics of tie-ins, Justice Scalia observed: "When that situation obtains, "no revenue can be derived from setting a higher price for the tied product which could not have been made by setting the

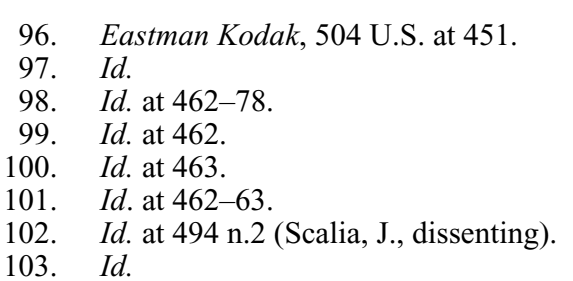


optimum price.",104 According to Justice Scalia, this single monopoly profit theorem "strongly suggest[ed] that Kodak parts and the service involved in installing them should not be treated as distinct products for antitrust tying purposes." 105

Another disagreement between the majority and the dissenters was whether a firm could incur antitrust liability for tying products in a derivative aftermarket (replacement parts for Kodak photocopiers) when competition already existed in the primary market for equipment (various brands of photocopiers). The majority rejected Kodak's claim that competition among photocopier manufacturers prevented it from raising prices of services and parts for its machines. The majority reasoned that, although it was true that interbrand competition for photocopiers prevented Kodak from charging the full supracompetitive price that it might have wanted to charge for parts and services, that interbrand competition did not necessarily prevent Kodak from charging a price that was above the competitive level: "The fact that the equipment market imposes a restraint on prices in the aftermarkets by no means disproves the existence of power in those markets." 106

The constraint that interbrand competition placed on Kodak's exploitation of intraband market power was, according to the Court, attenuated by Kodak's horizontal relationship with competing providers of repair services. ${ }^{107}$ The Court said that high information costs would prevent accurate lifecycle pricing, and most consumers, the majority feared, would be unable to calculate the total cost of equipment, replacement parts, and repair service. ${ }^{108}$ Furthermore, the majority said that high switching costs also allowed Kodak to exploit its customers, for "consumers who already have purchased the equipment, and are thus 'locked in,' will tolerate some level of serviceprice increases before changing equipment brands."109

Justice Scalia dissented. Virtually every manufacturer of a durable good, he noted, enjoys some form of market power with respect to unique products required for aftermarket support. ${ }^{110}$ However, he said, lacking interbrand market power, a firm could not "raise derivative market prices generally by reducing quantity," because, if Kodak set supracompetitive prices for parts or service, consumers would purchase equipment from Kodak's competitors. ${ }^{111}$ The Court's concern over high information costs

104. Id. (quoting Phillip AREEDA \& Louis KAPLOW, ANTITRUST ANALYsis $₫$ 426(a)

(4th ed. 1988) (quoting Bowman, supra note 45, at 19)).

105. Id. at $494-95$ n.2.

106. Id. at 471 (majority opinion).

107. Id. at 471 n. 18 .

108. Id. at 473

109. Id. at 476

110. Id. at 493 (Scalia, J., dissenting).

111. Id. at 495 . 
and switching costs was, in the assessment of the three dissenters, unfounded; both kinds of transaction costs pervaded real-world markets without attracting the concern of antitrust law. ${ }^{12}$ Consequently, the dissenters found that "[a] tie between two aftermarket derivatives does next to nothing to improve a competitive manufacturer's ability to extract monopoly rents from its consumers." 113 Although the majority in Kodak did not label tying as per se illegal, the dissenters finally argued that applying the per se rule to single-brand aftermarket tying arrangements would achieve nothing more than "releas[ing] a torrent of litigation and a flood of commercial intimidation." 114

Kodak's definition of tying raised criticism. Dennis Carlton, Herbert Hovenkamp, and other antitrust scholars have criticized Kodak for evaluating market power in an aftermarket when the market for the new durable product (photocopiers) is competitive. ${ }^{115}$

It is important that, in Kodak, the Supreme Court never called tying per se illegal. Because the case came to the Court on Kodak's motion for summary judgment, ${ }^{116}$ the Court did not need to decide whether precompetitive effects could outweigh the anticompetitive effects of Kodak's conduct. ${ }^{117}$ Nevertheless, the Court's reference to such balancing suggests an implicit qualification of tying as an antitrust offense that needs to be assessed under the rule of reason. ${ }^{118}$

112. Id. at $495-98$

113. Id. at 499 .

114. Id. at 489 .

115. See, e.g., Dennis W. Carlton, A General Analysis of Exclusionary Conduct and Refusal To Deal-Why Aspen and Kodak Are Misguided, 68 ANTITRUST L.J. 659, 679 (2001); Dennis W. Carlton \& Michael Waldman, Competition, Monopoly, and Aftermarkets, 26 J.L. ECON. \& ORG. 54 (2010); Daniel J. Gifford, The Damaging Impact of the Eastman Kodak Precedent Upon Product Competition: Antitrust Law in Need of Correction, 72 WASH. U. L.Q. 1507, 1533 (1994) (arguing that there was no plausible anticompetitive reason for Kodak's tying practice, and that Court should have presumed it was procompetitive); Herbert Hovenkamp, Market Power in Aftermarkets: Antitrust Policy and the Kodak Case, 40 UCLA L. REV. 1447, 1458-59 (1993) (observing low probability of exploitation in aftermarkets when foremarket is competitive).

116. Eastman Kodak, 504 U.S. at 456.

117. Id. at 478 .

118. See id. 


\section{Illinois Tool Works}

In Illinois Tool Works Inc. v. Independent Ink, Inc. in 2006, the Court, in a unanimous opinion by Justice Stevens (the author of the majority opinion in Jefferson Parish), overruled its presumption of market power when a firm holds a patent on a tying product. ${ }^{119}$ The Illinois Tool Works opinion praised Justice O'Connor's concurrence in Jefferson Parish and conspicuously declined to cite Kodak for any proposition. The Court recognized Justice O'Connor, who had retired from the Court two months before it issued its opinion in Illinois Tool Works, for having questioned in Jefferson Parish

not only the propriety of treating any tying arrangement as a per se violation of the Sherman Act, but also the validity of the presumption that a patent always gives the patentee significant market power, observing that the presumption was actually a product of our patent misuse cases rather than our antitrust jurisprudence. 120

Justice Stevens wrote that "Justice O'Connor was, of course, correct in her assertion that the presumption that a patent confers market power arose outside the antitrust context," and he called that presumption "a vestige of the Court's historical distrust of tying arrangements." 121

The Court in Illinois Tool Works said that "[m]any tying arrangements . . . are fully consistent with a free, competitive market." 122 The Court found it dispositive that Congress had eliminated the statutory presumption in patent misuse cases that a patent confers market power. ${ }^{123}$ The Court held that the per se rule should no longer be automatically applied to antitrust cases of tying arrangements involving patented products. ${ }^{124}$ The Court also rejected Independent Ink's alternative rule, which would have created either (1) a rebuttable presumption of market power when tying occurs, or (2) a presumption in cases where the sale of a patented tying product is conditional on the purchase of unpatented goods over time, known as a "requirements tie." 125 The Court thus rejected the proposition that the combination of a patent and a requirements tie were together enough to consider the tying arrangement per se unlawful. ${ }^{126}$ The Court emphasized that tying arrangements should raise competitive concerns only "when the

119. Ill. Tool Works Inc. v. Indep. Ink, Inc., 547 U.S. 28, 31 (2006).

120. Id. at 37-38 (citing Jefferson Par. Hosp. Dist. No. 2 v. Hyde, 466 U.S. 2, 35, 37 n.7 (1984)).

121. Id. at 38

122. Id. at 45 .

123. Id. at 41-42 (citing 35 U.S.C. § 271(d)(5) (2000 \& Supp. III 2003)).

124. Id. at 42 .

125. Id. 44-46.

126. See id. 
seller has some special ability - usually called 'market power' - to force a purchaser to do something that he would not do in a competitive market...."127 The Court held that the patent owner's market power should be evaluated on a case-by-case basis. ${ }^{128}$

Illinois Tool Works - through its subsidiary Trident, Inc. - manufactured and marketed printing systems, including patented print heads and ink containers. Trident also made unpatented, specially designed ink. It sold the printing systems to original equipment manufacturers (OEMs) that were licensed to incorporate the products into their own printing systems, which were themselves sold to companies needing specialized printing equipment. Independent Ink had developed its own ink, which was compatible with Trident's patented printing technologies. ${ }^{129}$

After defeating on jurisdictional grounds a patent infringement suit brought by Trident, Independent Ink filed a lawsuit seeking a declaratory judgment that Trident's patents were neither valid nor infringed and, further, claiming that Trident was engaged in illegal tying and monopolization in violation of sections 1 and 2 of the Sherman Act. ${ }^{130}$ The district court granted Trident summary judgment on both the tying and monopolization claims. ${ }^{131}$ The district court rejected the claim that Trident's patents meant that Trident "necessarily [had] market power in the market for the tying product as a matter of law ... thereby rendering [the] tying arrangements per se violations of the antitrust laws." 132 Summary judgment was appropriate, the district court held, because Independent Ink presented no other evidence regarding the relevant market or Trident's market power within any relevant market. ${ }^{133}$

The Federal Circuit reversed the decision, citing International Salt, ${ }^{134}$ Loew's, ${ }^{135}$ and Jefferson Parish ${ }^{136}$ for the proposition that possession of a

127. Id. at 36 (citing Jefferson Par. Hosp. Dist. No. 2 v. Hyde, 466 U.S. 2, 13-14 (1984)).

128. Id. at $42-43,46$.

129. Id. at $31-32$.

130. Id. at 32 .

131. Indep. Ink, Inc. v. Trident, Inc., 210 F. Supp. 2d 1155, 1177 (C.D. Cal. 2002), aff'd in part, rev'd in part sub nom. Indep. Ink, Inc. v. Ill. Tool Works, Inc., 396 F.3d 1342 (Fed. Cir. 2005), vacated, 547 U.S. 28 (2006).

132. Id. at 1159 .

133. Ill. Tool Works, 547 U.S. at 32.

134. Int'l Salt Co. v. United States, 332 U.S. 392 (1947).

135. United States v. Loew's Inc., 371 U.S. 38 (1962).

136. Jefferson Par. Hosp. Dist. No. 2 v. Hyde, 466 U.S. 2 (1984). 
patent on the tying product alone justifies a finding of market power over the tying product. ${ }^{137}$ The Federal Circuit signaled to the Supreme Court that "the 'fundamental error' in petitioners' submission was its disregard of 'the duty of a court of appeals to follow the precedents of the Supreme Court until the Court itself chooses to expressly overrule them." 138

The Court got the message. It said in a unanimous opinion that this was the "first case since 1947" in which it had reviewed the presumption of market power resulting from a patent, ${ }^{139}$ and that its "review [was] informed by extensive scholarly comment and a change in position by the administrative agencies charged with enforcement of the antitrust laws." began by reviewing the history of the per se rule outlawing tying arrangements under section 1 of the Sherman Act. It recounted the unanimous decision in Fortner II, in which the Court essentially held that a plaintiff cannot win a tying claim without proving that the defendant possesses market power in the relevant market for the tying product. ${ }^{141}$ Further, it addressed the Loew's decision, where the Court "described the rule that a contract to sell a patented product on condition that the purchaser buy unpatented goods exclusively from the patentee is a per se violation of $\S 1$ of the Sherman Act." "142 In citing Loew's, however, the Court emphasized that Loew's itself is not precedent for the proposition that a patent carries with it presumptive market power-Loew's is simply precedent for the proposition that a patented tying product may suffice to establish market power under the per se rule. ${ }^{143}$

The Court then described how the presumption of market power accompanying a patented product entered antitrust jurisprudence by way of the patent misuse doctrine. ${ }^{144}$ Those cases assumed — without analyzing market conditions - that "tying the purchase of unpatented goods to the

137. Indep. Ink, Inc. v. Ill. Tool Works Inc., 396 F.3d 1342, 1354 (Fed Cir. 2005).

138. Ill. Tool Works, 547 U.S. at 33 (quoting Indep. Ink, Inc., 396 F.3d at 1351).

139. Id. at 40

140. Id. at 33. The opinion was unanimous among eight Justices. Justice Alito did not participate in the case. Id. at 46. The Senate confirmed him as Associate Justice on January 31, 2006, two months after oral arguments in Illinois Tool Works. David Stout, Alito Is Sworn In as Justice After 58-42 Vote To Confirm Him, N.Y. TimES (Jan. 31, 2006), http://www.nytimes.com/2006/01/31/politics/politicsspecial1/31 cnd-alito.html?_r=0 [http:// perma.cc/G9L9-G4Z7].

141. Ill. Tool Works, 547 U.S. at 36; see also U.S. Steel Corp. v. Fortner Enters., Inc., 429 U.S. 610, 620-21 (1977) ("[T]he question is whether the seller has some advantage not shared by his competitors in the market for the tying product. Without any such advantage differentiating his product from that of his competitors, the seller's product does not have the kind of uniqueness considered relevant in prior tying-clause cases.").

142. Ill. Tool Works, 547 U.S. at 37.

143. Id. ("Notably, nothing in our opinion suggested a rebuttable presumption of market power applicable to tying arrangements involving a patent on the tying good.").

144. Id. at 38-40. 
sale of a patented good, the patentee was 'restraining competition."'145 The Court's decision formally importing the patent-as-market-power presumption into antitrust law was International Salt. ${ }^{146}$ The Illinois Tool Works Court noted that International Salt "clearly shows [that the Court] accepted the Government's invitation to import the presumption of market power in a patented product into our antitrust jurisprudence."147

After reciting the historical foundation for the patent-as-market-power presumption in detail, the Court described how Congress had been "chipping away" at the presumption ever since Fortner - the very decision that began the historical discussion. ${ }^{148}$ In particular, a 1988 amendment to the Patent Code ended the presumption of market power in patent misuse cases. ${ }^{149}$ The amendment provided that a patent holder may not be denied relief because the patent holder has "conditioned ... the sale of the patented product on the ... purchase of a separate product, unless ... the patent owner has market power in the relevant market for the ... patented product on which the ... sale is conditioned." 150 Although the amendment did not refer specifically to antitrust law, the Court said that "given the fact that the patent misuse doctrine provided the basis for the market power presumption, it would be anomalous to preserve the presumption in antitrust after Congress has eliminated its foundation."151 The 1988 amendment to the Patent Code was dispositive for the Court: "After considering the congressional judgment reflected in the 1988 amendment, we conclude that tying arrangements involving patented products should be evaluated under the standards applied in cases like Fortner II and Jefferson Parish rather than under the per se rule applied in Morton Salt and Loew's."152 The Court noted that its decision comported "with the vast majority of the academic literature on the subject."153

Independent Ink, correctly predicting that the Court would abandon the market power presumption, argued for two alternative presumptions of market power in tying cases involving patents. The Court rejected both. ${ }^{154}$

145. Id. at 38 (citing Morton Salt Co. v. G.S. Suppiger Co, 314 U.S. 488, 490 (1942))

146. Id. at 38-39 (citing Int'l Salt Co. v. United States, 332 U.S. 392 (1947)).

147. Id. at 39 (citing Int'l Salt, 332 U.S. 392).

148. Id. at 41 (citing Fortner Enters. v. U.S. Steel Corp., 394 U.S. 495, 503 (1969)).

149. Id. 41-42 (quoting 35 U.S.C. § 271(d)(5) (2000 \& Supp. III 2003)).

150. 35 U.S.C. $\$ 271(\mathrm{~d})(5)$.

151. Ill. Tool Works, 547 U.S. at 42.

152. Id.

153. Id. at 43 n. 4 .

154. Id. at $44-45$. 
The first theory suggested "a rebuttable presumption that patentees possess market power when they condition the purchase of the patented product on an agreement to buy unpatented goods exclusively from the patentee." 155 The Court, distinguishing the circumstances in Illinois Tool Works from those surrounding the opinion rendered in International Salt - upon which Independent Ink had relied as an authority-rejected this theory. ${ }^{156}$

Independent Ink's second theory presumed market power in the case of "a tying arrangement involving the purchase of unpatented goods over a period of time - a so-called 'requirements tie."'157 Independent Ink argued that such tying is a means for charging large-volume purchasers a higher royalty for use of the patent than small purchasers must pay - a form of discrimination that " is strong evidence of market power."” 158 Relying on an article by William Baumol and Daniel Swanson, the Court rejected Independent Ink's proposition that price discrimination is evidence of market power and recognized that price discrimination "also occurs in fully competitive markets." "159 The Court had just ruled - three paragraphs earlier - that a patent by itself is an insufficient basis from which to infer market power, ${ }^{160}$ and, because price discrimination does not prove the existence of market power, the Court was "not persuaded that the combination of these two factors should give rise to a presumption of market power when neither is sufficient to do so standing alone." 161 To the contrary, the Court said that "the lesson to be learned from International Salt and the academic commentary is the same: Many tying arrangements, even those involving patents and requirements ties, are fully consistent with a free, competitive market." 162

Following Congress, the antitrust enforcement agencies, and many economists, the Court held that, "in all cases involving a tying arrangement,

155. Id. at 43 .

156. Id. at 44 (citing Int'l Salt Co. v. United States, 332 U.S. 392, 395-96 (1947)).

157. Id.

158. Id. (quoting Brief for Respondent at 27, Ill. Tool Works Inc. v. Indep. Ink, Inc., 547 U.S. 28 (2006) (No. 04-1329), 2005 WL 2427645.

159. Id. at 44-45 (citing William J. Baumol \& Daniel G. Swanson, The New Economy and Ubiquitous Competitive Price Discrimination: Identifying Defensible Criteria of Market Power, 70 ANTITRUST L.J. 661, 666 (2003)).

160. To reiterate the point, the Court referenced the guidelines that the Department of Justice and the Federal Trade Commission published in 1995 in which the agencies announced that, as matter of prosecutorial discretion, they would not follow the patent-asmarket-power presumption. Id. at 45 (citing U.S. DEP'T OF JUSTICE \& FED. TRADE COMM'N, Antitrust GUidelines for the Licensing of InTEllectual Property § 2.2 (1995), http://www.usdoj.gov/atr/public/guidelines/0558.pdf [http://perma.cc/K78G-BHJ7]).

161. Id.

162. Id. 
the plaintiff must prove that the defendant has market power in the tying product." "63 Because Independent Ink had not addressed the market power issue at trial, the Court reversed the Federal Circuit, vacated the judgment, and remanded the case to the district court to determine whether Illinois Tool Works possessed market power over the tying patented product. ${ }^{164}$

\section{The Implicit Recognition of Efficiencies as an Affirmative Defense}

Although the Supreme Court has not explicitly included efficiency justifications in its four-element test applied to tying arrangements, both the Court and the lower federal courts have accounted for efficiencies as an affirmative defense to tying.

First, the two-products test applied in the per se analysis represented a proxy for evaluation of the potential efficiencies of the tying arrangement. In Jefferson Parish, the Supreme Court ruled that the question of whether two separate goods should be considered an individual product must be examined in light of direct and indirect evidence of consumer demand. ${ }^{165}$ As explained by the D.C. Circuit, this analysis allows the court to considerto a limited extent - the possible efficiencies resulting from the tying arrangement. ${ }^{166}$ Unless the bundle provides some efficiency, consumers would always buy the two goods separately. Therefore, if some consumers prefer to buy the two products as part of a bundle (even in the absence of coercion), then the bundling provides some efficiency. In that case, the two goods might be considered an individual product, rather than two separate products, for the purpose of the tying analysis, and the per se prohibition should not apply. Similarly, firms without market power would not offer the separate products as part of the bundle unless there is an economic justification for the tying practice.

This approach has been largely embraced by lower courts, which have been prone to make a "'single product' disposition of tying claims because they saw tying doctrine as over-aggressive, long dispensing with real market power and effects and often ungenerous toward defenses." 167 For example, in United States v. Jerrold Electronics Corp., the district court

163. Id. at $45-46$.

164. Id. at 46.

165. Jefferson Par. Hosp. Dist. No. 2 v. Hyde, 466 U.S. 2, 21-22 (1984).

166. United States v. Microsoft Corp., 253 F.3d 34, 87 (D.C. Cir. 2001).

167. 10 AREEDA \& HOVENKAMP, supra note $45,91760 \mathrm{c}$. 
concluded (in a case that the Supreme Court summarily affirmed) that, if it is reasonable for the defendant to sell products only as a bundle, the bundle should be considered a single product. ${ }^{168}$ Jerrold sold cable television antenna systems for communities that were too remote to receive overthe-air television broadcasts. The district court found that "Jerrold's policy of full system sales was a necessary adjunct to its policy of compulsory service and was reasonably regarded as a product as long as the conditions which dictated the use of the service contract continued to exist." 169

Second, the Supreme Court in Kodak implicitly accepted the possibility of the application of efficiency defenses in per se tying cases. In Kodak, the Court ruled against Kodak and affirmed the lower courts' denial of summary judgment. The Court noted that Kodak's conduct "is simply not one that appears always or almost always to enhance competition, and therefore to warrant a legal presumption without any evidence of its actual economic impact." 170 However, the Court did not reject the proposition that efficiency justifications can save per se unlawful tying. To the contrary, the Court recognized that, "[i]n the end, of course, Kodak's arguments may prove to be correct. It may be that . . . any anticompetitive effects of Kodak's behavior are outweighed by its competitive effects." ${ }^{171}$ Because the record was sparse, the Court left the factual analysis of Kodak's justifications to the trial court. ${ }^{172}$ Therefore, it is incorrect to infer from Kodak that current Supreme Court jurisprudence does not recognize an efficiency defense for supposedly per se unlawful tying.

\section{THE D.C. CIRCUIT'S RULE OF REASON ANALYSIS FOR SOFTWARE INTEGRATION}

In 2001 in United States v. Microsoft Corp. (Microsoft III), the U.S. Court of Appeals for the District of Columbia, sitting en banc and speaking unanimously, abandoned the Supreme Court's four-part test for tying arrangements when analyzing allegations of tying taking the form of software integration. ${ }^{173}$

168. United States v. Jerrold Elecs. Corp., 187 F. Supp. 545, 560 (E.D. Pa. 1960), aff'd per curiam, 365 U.S. 567 (1961); see also 10 AREEDA \& HOVENKAMP, supra note 45, II $1756 \mathrm{a}$.

169. Jerrold Elecs., 187 F. Supp. at 560.

170. Eastman Kodak Co. v. Image Tech. Servs., Inc., 504 U.S. 451, 479 (1992).

171. Id. at 486

172. Id.

173. United States v. Microsoft Corp., 253 F.3d 34, 84, 89, 95 (D.C. Cir. 2001) (per curiam). 


\section{A. Microsoft II}

The concern with Microsoft's tying practice first arose in United States v. Microsoft Corp. (Microsoft II). ${ }^{174}$ In 1994, the U.S. Department of Justice filed a complaint against Microsoft, claiming that the company's licensing agreements with OEMs and other related practices were anticompetitive. The complaint was accompanied by a proposed consent decree intended to regulate practices for which remedies had been negotiated between Microsoft and the Department of Justice. This decree included section IV(E), which both Microsoft and the Department characterized as an "anti-tying" provision. After entering into the consent decree, Microsoft released its new browser, Internet Explorer (IE) 3.0, when it unveiled Windows 95 in July 1995. All copies of Windows 95 installed by OEMs included a version of IE. In early 1998, the Department of Justice petitioned the U.S. District Court in Washington, D.C. to hold Microsoft in civil contempt for its bundled licensing of its Windows 95 OS and IE 3.0, and to enjoin Microsoft from employing similar agreements with respect to any version of IE in the future. The Department contended that Microsoft's licensing practice violated section IV(E)(i) of the 1995 consent decree by effectively conditioning the license for Windows 95 on the license for IE, which, in the government's view, created a tie-in between the OS and the Web browser. ${ }^{175}$ The D.C. Circuit's decision in Microsoft II arose from the appeal of the district court's preliminary injunction that prohibited Microsoft from requiring computer manufacturers that were licensed to install the company's OS software, Windows 95, to also secure a license to install Microsoft's IE. ${ }^{176}$

The case or controversy before the D.C. Circuit was not whether Microsoft had violated the Sherman Act or section 3 of the Clayton Act. Rather, the D.C. Circuit was interpreting section IV(E)(i) of the Justice Department's 1994 consent decree with Microsoft. ${ }^{177}$ The court was thus ostensibly interpreting a contractual provision in light of the intentions of the contracting parties. Nonetheless, it is equally clear that, in interpreting what both parties to the consent decree acknowledged to be an "antitying" provision that must be interpreted with "procompetitive goals in mind," the D.C. Circuit's substantive legal and economic reasoning was

174. United States v. Microsoft Corp., 147 F.3d 935, 938-41 (D.C. Cir. 1998).

175. Id. at 939 .

176. Id. at 938

177. Id. at 939 . 
indistinguishable from the reasoning that it would have applied if deciding what constitutes an unlawful tying arrangement under then-current antitrust law. ${ }^{178}$

The D.C. Circuit turned explicitly to antitrust law and related economic principles to resolve the definition of an integrated product. The D.C. Circuit made clear that its interpretation of an integrated product reflected not only the understanding of the parties regarding the consent decree, but also that "this understanding is consistent with tying law." 179 Writing for the court, Judge Stephen Williams was careful to distinguish the issues relevant to software integration and the "separate consumer demand" standard used by the Supreme Court in Jefferson Parish and Kodak, and he questioned the applicability of the Kodak rule of "separate consumer demand" to technological tying. Judge Williams said that an "integrated product" is "most reasonably understood as a product that combines functionalities, which may also be marketed separately and operated together, in a way that offers advantages unavailable if the functionalities are bought separately and combined by the purchaser."180 Judge Williams stressed that the proper "analysis does not require a court to find that an integrated product is superior to its stand-alone rivals." 181 "The question," Judge Williams concluded, "is not whether the integration is a net plus but merely whether there is a plausible claim that it brings some advantage." 182

Applying its product integration rule to the facts before it in Microsoft $I I$, the D.C. Circuit found that Microsoft "met the burden of ascribing facially plausible benefits to its integrated design as compared to an OS combined with a stand-alone browser such as Netscape's Navigator."183

178. Id. at 946

179. Id. at 950

180. Id. at 948 .

181. Id. at 950; see also ILC Peripherals Leasing Corp. v. Int'l Bus. Machs. Corp., 458 F. Supp. 423, 439 (N.D. Cal. 1978) ("Where there is a difference of opinion as to the advantages of two alternatives which can both be defended from an engineering standpoint, the court will not allow itself to be enmeshed 'in a technical inquiry into the justifiability of product innovations.'” (quoting Response of Carolina, Inc. v. Leasco Response, Inc., 537 F.2d 1307, 1330 (5th Cir. 1976))), aff'd per curiam sub nom. Memorex Corp. v. Int'1 Bus. Machs. Corp., 636 F.2d 1188 (9th Cir. 1980)).

182. Microsoft, 147 F.3d at 950 (second emphasis added).

183. Id. The D.C. Circuit explained:

Incorporating browsing functionality into the operating system allows applications to avail themselves of that functionality without starting up a separate browser application. Further, components of IE 3.0 and even more IE 4 - especially the HTML reader-provide system services not directly related to Web browsing, enhancing the functionality of a wide variety of applications. Finally, IE 4 technologies are used to upgrade some aspects of the operating system unrelated to Web browsing. For example, they are used to let users customize their "Start" menus, making favored applications more readily available. They also make 
Judge Williams wrote that "a broad injunction against such behavior generally would not be consistent with the public interest." "184

\section{B. Microsoft III}

Microsoft II supplied the intellectual foundation for formally extending to software integration a more deferential antitrust rule for product integration than courts had traditionally applied to tying arrangements in technologically mature markets. In 1998, the Department of Justice and, separately, a group of twenty states and the District of Columbia filed civil lawsuits against Microsoft asserting multiple violations of federal antitrust law. ${ }^{185}$ The complaint alleged that Microsoft purposefully engaged in a series of actions designed to preserve a monopoly in the personal computer OS market and to extend that monopoly to the Internet browser market. $^{186}$

\section{The District Court's Findings of Fact}

Following a lengthy bench trial, Judge Thomas Penfield Jackson, in November 1999, issued findings of fact that overwhelmingly accepted the factual allegations against Microsoft. ${ }^{187}$ Judge Jackson concluded, as the Department of Justice had contended, that Microsoft perceived the emergence of cross-platform middleware - and particularly of Netscape's Navigator browser - as a threat to its monopoly in the PC operating systems market. ${ }^{188}$ Judge Jackson found that Microsoft feared technologies such as Netscape, because those technologies could run on multiple

possible "thumbnail" previews of files on the computer's hard drive, using the

HTML reader to display a richer view of the files' contents. Id. at $950-51$ (citation omitted).

184. Id. at 951 (quoting 59 Fed. Reg. 59,426, 59,428 (Nov. 17, 1994) (relating to the Department of Justice discussion of public comments submitted in the Tunney Act proceeding concerning the 1994 consent decree with Microsoft)).

185. Complaint, United States v. Microsoft Corp., (D.D.C. May 18, 1998) (No. 981232), 1998 WL 35241886 [hereinafter DOJ Microsoft Complaint]; Complaint, State of New York ex. rel. Vacco v. Microsoft Corp. (D.D.C. May 18, 1998) (No. 98-1233) [hereinafter State Microsoft Complaint].

186. DOJ Microsoft Complaint, supra note 185, paras. 1-38, 53-123; State Microsoft Complaint, supra note 185, paras. 9-78; Plaintiffs' Joint Proposed Conclusions of Law at 1-2, 2-54, 66-70, United States v. Microsoft Corp. (D.D.C. 1999) (Nos. 98-1232, 981233).

187. See United States v. Microsoft Corp., 84 F. Supp. 2d 9 (D.D.C. 1999).

188. Id. at $27-31$. 
operating systems - hence the denomination "cross-platform" - and they exposed their own application programming interfaces (APIs) on which software developers could rely in lieu of the APIs exposed in the underlying OS. ${ }^{189}$ If middleware programs became widely used, then large numbers of software developers would have sufficient incentive to write applications that relied entirely on middleware APIs, and developers and consumers alike would no longer rely on Windows as an applications platform. In Judge Jackson's view, Microsoft recognized that, if Navigator emerged "as the standard software employed to browse the Web," then large numbers of developers would write software applications that ran on its APIs and Navigator could thereby erode the applications barrier to entry in the PC OS. ${ }^{190}$

Accordingly, Microsoft sought to prevent Navigator from becoming the standard by maximizing IE's market share at "Navigator's expense."191 Judge Jackson found that, despite Microsoft's large investment in IE and the potential to obtain significant revenues from its sale, Microsoft integrated IE with Windows OS and offered IE for free. ${ }^{192}$ Judge Jackson conceded that Microsoft might have given IE away for free to respond to competition rather than to preserve the applications barrier to entry. ${ }^{193} \mathrm{He}$ concluded, however, that Microsoft's determination to preserve that barrier "was the main force driving its decision to price the product at zero."194 Judge Jackson also concluded that Microsoft foreclosed the OEM distribution channel to Navigator by prohibiting OEMs from removing IE from Windows or from altering or customizing the Windows boot-up sequence. ${ }^{195}$ Judge Jackson found that Microsoft reasoned correctly that the restriction against removing IE would deter OEMs from loading Navigator onto their PCs because to do so would increase support costs and consumer confusion, to the point where OEMs' profits on the sale of a computer would be depressed. ${ }^{196}$

Judge Jackson concluded that browsers and operating systems were two separate products because consumers sought to purchase them separately and because there was general agreement within the software industry that the functionalities provided by these two products were distinct. ${ }^{197}$ Given the demonstration by the Department of Justice at trial that IE could be

$\begin{array}{ll}\text { 189. } & I d . \text { at } 29-30 . \\ 190 . & I d . \text { at } 43 . \\ 191 . & I d . \text { at } 45 . \\ 192 . & I d . \text { at } 44 . \\ 193 . & I d . \\ 194 . & I d . \\ 195 . & I d . \text { at } 58-59 . \\ 196 . & I d . \text { at } 49-50 . \\ 197 . & I d . \text { at } 48 .\end{array}$


removed without harming the functionality of Windows, Judge Jackson found that no technical reason existed for Microsoft to prohibit consumers from removing IE from Windows. ${ }^{198}$ Judge Jackson was not persuaded by Microsoft's arguments regarding the technical virtues of combining IE and Windows. He concluded that Microsoft integrated browsing-specific routines with operating-system routines "to a greater degree than is necessary to provide any consumer benefit." 199 Consequently, he concluded that Microsoft thereby "unjustifiably jeopardized the stability and security of the operating system," not only for consumers who wanted a browser, but also for consumers who did not. ${ }^{200}$ He further found that the integration of IE and Windows reduced the speed of PCs, a disadvantage for consumers who did not want a browser. ${ }^{201}$ Judge Jackson concluded that Microsoft integrated IE into Windows not for any procompetitive purpose, but purely to restrict the distribution of Netscape Navigator and to stop "Navigator from weakening the applications barrier to entry." ${ }^{202}$ He also maintained that Microsoft's actions were profitable only to the extent that they preserved an applications barrier to entry. ${ }^{203}$

\section{The D.C. Circuit's Unanimous En Banc Opinion}

In a unanimous en banc opinion issued per curiam, the D.C. Circuit affirmed the finding of unlawful maintenance of monopoly power in the market for PC operating systems. ${ }^{204}$ The D.C. Circuit agreed with Judge Jackson that the challenged practices had anticompetitive effects and that Microsoft had failed to present any valid business justification for the practices. The D.C. Circuit concluded that Microsoft's conduct constituted an act of monopolization in violation of section 2 of the Sherman Act. ${ }^{205}$

However, the D.C. Circuit rejected Judge Jackson's ruling that Microsoft attempted to monopolize the browser market. ${ }^{206}$ The D.C. Circuit held that it was "far too speculative to establish that competing browsers would be unable to enter the market, or that Microsoft would have the power to

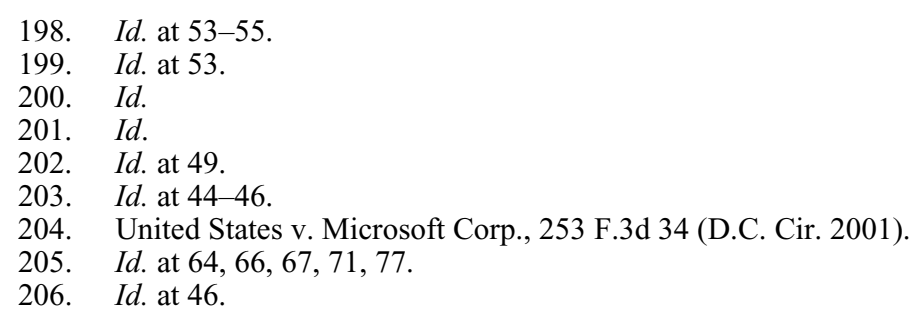


raise the price of its browser above, or reduce the quality of its browser below, the competitive level." ${ }^{207}$ In particular, the D.C. Circuit criticized Judge Jackson's failure to explain the presence of relevant barriers to entry into the browser market that would enable Microsoft to monopolize that market. ${ }^{208}$ Finally, and of greatest relevance to Google's bundling of free mobile apps with Android, the D.C. Circuit reversed and remanded Judge Jackson's determination that Microsoft's tying of IE to the Windows OS constituted a per se violation of section 1 of the Sherman Act. ${ }^{209}$

The D.C. Circuit first evaluated whether IE and the Windows OS should be considered separate products. ${ }^{210}$ The D.C. Circuit analyzed the approach adopted in Jefferson Parish, in which the Supreme Court maintained that no tying arrangement can exist unless there is sufficient demand to purchase the two products separately. ${ }^{211}$ In evaluating the existence of consumer demand for the tied product separate from consumer demand for the tying product, the Supreme Court accounted for both direct evidence - consumers' demand for the individual product - and indirect evidence - firms' practice of offering the two products as a bundle. ${ }^{212}$ The D.C. Circuit explained that " $[\mathrm{t}] \mathrm{he}$ consumer demand test is a rough proxy for whether a tying arrangement may, on balance, be welfare-enhancing, and unsuited to per se condemnation." 213 The D.C. Circuit reasoned that "[o]nly when the efficiencies from bundling are dominated by the benefits to choice for enough consumers ... will we actually observe consumers making independent purchases." "214 In other words, consumer demand for the separate products is "inversely proportional to net efficiencies" of tying. ${ }^{215}$ Similarly, the D.C. Circuit observed that firms will offer the two products in a bundle "only when the cost savings from joint sale outweigh the value consumers place on separate choice." 216 Therefore, "bundling by all competitive firms implies strong net efficiencies" of the bundling practice. ${ }^{217}$ The D.C. Circuit ruled that, when there is no convincing evidence of separate demand and when other firms engage in the same behavior as the

$\begin{array}{ll}\text { 207. } & \text { Id. } \text { at } 83 . \\ 208 . & I d . \text { at } 82 . \\ 209 . & I d . \text { at } 84 . \\ 210 . & I d . \text { at } 85 . \\ 211 . & I d . \text { at } 85-86 . \\ 212 . & \text { Id. } \text { at } 86 . \\ 213 . & \text { Id. } \text { at } 87 . \\ 214 . & \text { Id. } \\ 215 . & \text { Id. at } 87-88 . \\ 216 . & I d . \text { at } 88 . \\ 217 . & \text { Id. }\end{array}$


defendant, the tying and the tied product should be declared one single product, and per se liability should be rejected. ${ }^{218}$

Further, the D.C. Circuit questioned the adequacy of the separate-products test adopted in Jefferson Parish for scrutinizing product integration in technologically dynamic markets. ${ }^{219}$ The court considered Microsoft's argument that the integration of IE and Windows was innovative and beneficial. Although the court recognized that Microsoft's licensing practice had failed the efficiency balancing test that the court performed under its monopoly maintenance scrutiny, when analyzing whether the licensing practice allowed Microsoft to maintain monopoly power in the PC operating systems market, it noted that the separate-products analysis is a screening test and consequently it "is supposed to perform its function as a proxy without embarking on any direct analysis of efficiency." ${ }^{220}$ Accordingly, the court ruled that there was merit to Microsoft's argument that "Jefferson Parish's consumer demand test would 'chill innovation to the detriment of consumers by preventing firms from integrating into their products new functionality previously provided by standalone products - and hence, by definition, subject to separate consumer demand."'221 The court noted, however, that the separate-demand analysis might be an inadequate proxy for evaluating potentially innovative technological integration. The court observed that backward-looking inquiries into consumer demand and industry custom - direct and indirect evidence about consumer demandwere ill suited to determine the efficiencies arising from "new and innovative integration." 222 As the court explained, "[t]he direct consumer demand test focuses on historic consumer behavior ... and the indirect industry custom test looks at firms that, unlike the defendant, may not have integrated the tying and tied goods." 223 The D.C. Circuit emphasized that the consumer demand test might ignore the efficiency benefits that integration might bring to consumers. ${ }^{224}$ The D.C. Circuit accepted Microsoft's argument that the integration of IE into Windows was innovative and could benefit consumers. ${ }^{225}$

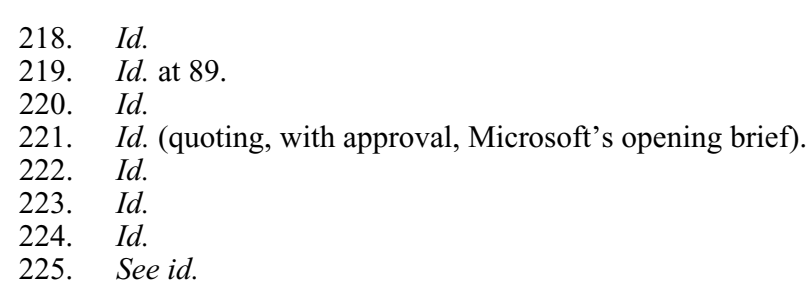


Scholars in law and economics have applauded the D.C. Circuit's approach to evaluating the existence of separate products. The AreedaHovenkamp treatise had, in 1999, anticipated this critique of the separate-products test in the context of software integration. ${ }^{226}$ Commenting on the "artificiality of the separate products requirement" in Judge Jackson's decision, the treatise noted that, "for purposes of measuring the anticompetitive effects of Microsoft's bundling practice, it is of little importance whether the Windows 95 operating platform and the Internet browser were once sold separately." 227 I, too, had argued, in anticipation of the D.C. Circuit's 2001 decision in Microsoft, that a more appropriate inquiry is whether the offered bundle represents the creation of an entirely new source of consumer surplus. ${ }^{228}$ Has an entirely new demand curve come into existence? Is this a product for which virtually no demand existed a few years earlier? Will consumers benefit from the product integration? The failure to address these questions would condemn tying agreements that increase consumer welfare.

Further, the D.C. Circuit considered and rejected the applicability of the per se rule to software integration. Quoting Jefferson Parish, the D.C. Circuit recognized that certain tying practices "pose an unacceptable risk of stifling competition and therefore are unreasonable 'per se'.,229 However, it emphasized that "[i]t is only after considerable experience with certain business relationships that courts classify them as per se violations." 230 The D.C. Circuit noted that Microsoft's licensing practice was very different from any previous tying case that the Supreme Court had heard. ${ }^{231}$ The D.C. Circuit distinguished software integration cases from the Supreme Court's precedents on tying; none of the Court's decisions addressed "physically and technologically integrated" products, nor did the sellers in those cases argue that tying "improved the value of the tying product to users and makers of complementary goods." 232 The D.C. Circuit determined that judicial experience provided little basis for concluding that "a software firm's decisions to sell multiple functionalities as a package should be "conclusively presumed to be unreasonable and therefore illegal

226. See, e.g., 10 AreEda \& HovenKamp, supra note 45, 1 1746.1a (2d ed. Supp. 1999).

227. Id.

228. Sidak, supra note 30, at 33-47 (discussing the need for tying analysis to consider whether the market is technologically dynamic).

229. Microsoft, 253 F.3d at 89 (quoting Jefferson Par. Hosp. Dist. No. 2 v. Hyde, 466 U.S. $2,9(1984))$.

230. Id. at 84 (quoting Broad. Music, Inc. v. Columbia Broad. Sys., Inc., 441 U.S. 1, 9 (1979)).

231. Id. at 90 .

232. Id. 
without elaborate inquiry as to the precise harm they have caused or the business excuse for their use."'233

The D.C. Circuit said that applying the per se rule to software integration could "produce inaccurate results" and deter "valuable innovation." 234 First, it reasoned, "the separate-products test is a poor proxy for net efficiency from newly integrated products." ${ }^{235}$ The D.C. Circuit observed that the use of the rule of reason would instead allow the defendant to demonstrate that "an efficiency gain from its 'tie' adequately offsets any distortion of consumer choice." 236 Second, tying arrangements integrating software could create "efficiencies" and procompetitive effects "[neither] encountered ... [nor] factored into the per se rule" as decided in previous cases. ${ }^{237}$ Thus, the D.C. Circuit determined that the "wooden application of per se rules" ${ }^{\prime 238}$ would be inappropriate in markets with a "pervasively innovative character."239 Doing so would elevate the risk of "stunt[ing] valuable innovation." 240

Finally, the D.C. Circuit said that it did not have "enough empirical evidence regarding the effect of Microsoft's practice on the amount of consumer surplus created or consumer choice foreclosed by the [software] integration ... to exercise sensible judgment regarding that entire class of behavior."241 The court reasoned that it simply did not know enough about the impact of Microsoft's licensing practice on competition to classify it as a per se violation. ${ }^{242}$

The D.C. Circuit consequently found that "the rule of reason, rather than per se analysis, should govern the legality of tying arrangements involving platform software products." ${ }^{243}$ The D.C. Circuit said that a court applying the rule of reason test should focus on whether the integration results in

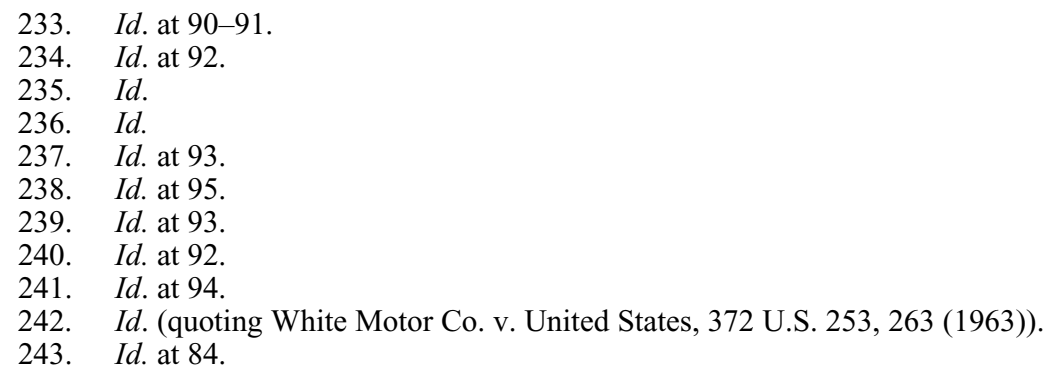


actual harm to competition in the relevant market. ${ }^{244}$ Antitrust scholars have endorsed the D.C. Circuit's reasoning. ${ }^{245}$

At the least, the Supreme Court has acquiesced in the D.C. Circuit's rule of reason approach to software integration. Though Microsoft was the most consequential antitrust case in a generation, the Court denied certiorari in the appeal of the D.C. Circuit's decision. ${ }^{246}$ More than a decade has passed since Microsoft III without the Supreme Court taking a case to clarify the law. There is no reason to believe that the Court disagrees with the D.C. Circuit's unanimous en banc conclusion that courts should evaluate software integration under the rule of reason.

\section{THE MADA AND GOOGLE's Business MODEL}

Google has compelling business justifications to make its apps available for preloading only under the conditions specified in the MADA. The MADA's requirements promote the appeal of Android-operated devices that use GMS and thus maintain Android's competitiveness in the market for mobile platforms. The viability of an open platform in turn facilitates Google's participation in the mobile device industry.

\section{A. The Android OS, Google Apps, and the Suite of Google Mobile Services}

Google offers a variety of products for mobile devices: the Android OS and multiple Google apps, which are available to consumers both separately and as part of GMS. Understanding the key features of and the relationship between those products is necessary to evaluating the effects that the MADA has on competition and, ultimately, consumers.

244. Id. at 95 (citing Jefferson Par. Hosp. Dist. No. 2 v. Hyde, 466 U.S. 2 , 29 (1984)); see also David A. Heiner, Assessing Tying Claims in the Context of Software Integration: A Suggested Framework for Applying the Rule of Reason Analysis, 72 U. CHI. L. REV. 123, 146 (2005) (stating that the rule of reason test must be applied with a "focus on whether the integration results in actual harm to competition in the 'market' ... or, conversely, whether the integrated product ... preserve[s] competitive opportunities").

245. See, e.g., Heiner, supra note 244; Christian Ahlborn, David S. Evans \& A. Jorge Padilla, The Antitrust Economics of Tying: A Farewell to Per Se Illegality, 49 ANTITRUST BuLl. 287, 301-03 (2004).

246. Microsoft Corp. v. United States, 534 U.S. 952 (2001) (mem.). 


\section{The Android $O S$}

Android is a mobile operating system. It coordinates all hardware and software functions for mobile devices, such as smartphones and tablets. ${ }^{247}$ Android, Inc., a start-up founded in 2003 in Palo Alto, California, initially developed Android. ${ }^{248}$ In 2005, Google acquired Android, Inc. and "set about the ambitious goal of creating a new mobile operating system that would allow open interoperation across carriers and manufacturers."249 As a leading member of the Open Handset Alliance (OHA) - a consortium of 84 mobile operators, handset manufacturers, semiconductor companies, software companies, and commercialization companies committed to developing open standards for mobile devices-Google was a major contributor to the initial development and launch of Android. ${ }^{250}$ As of July 2015, Google continues to invest in the development of Android: Google leads the Android Open Source Project- "the people, the processes, and the source code that make up Android"-overseeing the further development of the Android OS. ${ }^{251}$

Android is an open-source OS offered free of charge. ${ }^{252}$ Unlike a closed-source OS, the code of an open-source OS is typically, though not always, available free of charge to the public - that is, to manufacturers, mobile carriers, and individual users - to use and distribute on their mobile devices. ${ }^{253}$ These stakeholders may also customize Android's

247. Android, the World's Most Popular Mobile Platform, ANDROID, http://developer. android.com/about/android.html [http://perma.cc/3QKE-ZT33] (last visited June 24, 2015).

248. A Brief History of Android OS, HeATWARE (Apr. 15, 2014) http://www. heatware.net/linux-unix/brief-history-android/ [http://perma.cc/UXJ2-XBWM].

249. Sergey Brin \& Larry Page, Founders' Letter, in Google Inc., 2008 Annual Report (Form 10-K) (Feb. 13, 2009) [hereinafter Google Founders' Letter], http://investor. google.com/pdf/2008_google_annual_report.pdf [http://perma.cc/UL4R-C8BA].

250. See OPEn HANDSET Alliance, http://www.openhandsetalliance.com [http:// perma.cc/Z5TN-65LP] (last visited Aug. 11, 2015).

251. See Frequently Asked Questions, ANDROID, https://source.android.com/source/ faqs.html [https://perma.cc/XSX6-LQ9L] (last visited Aug. 11, 2015).

252. The Android Source Code, ANDROID, http://source.android.com/source/index. html [http://perma.cc/2UZ4-RDAM] (last visited June 24, 2015). But see Katherine Noyes, Is Android Open? Not So Much, Study Finds, PCWORLD (Dec. 13, 2011, 12:49 PM), http://www.pcworld.com/article/246140/is_android_open_not_so_much_study_finds.html [http://perma.cc/6ZXM-AKQP] (disputing the "openness" of Android).

253. Apache License, Version 2.0, APACHE Software Found. (Jan. 2004), http:// www.apache.org/licenses/LICENSE-2.0 [http://perma.cc/PK6C-EUKS]. 
features to meet their individual needs. ${ }^{254}$ Further, any developer may create mobile apps that run on Android. ${ }^{255}$

Google released the Android OS in 2007, and the first Android-operated smartphones were launched in 2008. ${ }^{256}$ Android "rapidly grew in popularity." 257 According to Google's 2013 annual report, there were "more than a billion Android devices activated globally as of September 2013."258 However, because Android is free, Google does not generate any direct profit from this widespread use of Android.

Android is not the only OS available for mobile devices. Some alternative operating systems are proprietary and closed, whereas others are open. Furthermore, some proprietary operating systems are available on an exclusive basis, while others are freely licensed to any mobile device manufacturer. For example, Apple iOS is a closed and proprietary OS exclusively available on Apple's mobile devices, such as the iPhone and iPad. ${ }^{259}$ No other mobile device manufacturer may lawfully install iOS on its devices. Similarly, the Blackberry OS, developed by Blackberry Ltd. (formerly Research in Motion), is a proprietary OS available only on Blackberry devices. ${ }^{260}$ In contrast, Windows Phone, the OS developed by Microsoft, is a closed and proprietary OS that is nevertheless available on a nonexclusive basis to any manufacturer. ${ }^{261}$ For example, Samsung offers

254. Welcome to the Android Open Source Project!, ANDROID, https://source. android.com/ [https://perma.cc/V47X-GTTR] (last visited May 28, 2015); see also Rita El Khoury, How to Customize Everything About Your Android Device, APPSTORM (Apr. 16, 2013), http://android.appstorm.net/how-to/customization/how-to-customize-everythingabout-your-android-device/ [http://perma.cc/HN6U-AE44] (last visited Aug. 11, 2015); Scott Webster, Customize Your Android Home Screen Experience, CNET (May 4, 2015, 10:23 AM), http://www.cnet.com/news/customize-your-android-home-screen-experience/ [http://perma.cc/EVS8-XXPW].

255. Android Lollipop, ANDROID DEVELOPERS, http://developer.android.com/about/ versions/lollipop.html [http://perma.cc/WWB3-2UX3] (last visited Aug. 11, 2015).

256. Google Founders' Letter, supra note 249; T-Mobile G1: Full Details of the HTC Dream Android Phone, GizMODo (Sept. 23, 2008, 10:30 AM), http://gizmodo.com/ 5053264/t-mobile-g1-full-details-of-the-htc-dream-android-phone [http://perma.cc/Z4L9-FLTP].

257. Oracle Am., Inc. v. Google Inc., 872 F. Supp. 2d 974, 978 (N.D. Cal. 2012).

258. Google Inc., Annual Report (Form 10-K), at 3 (Feb. 11, 2014), https://investor. google.com/pdf/20131231_google_10K.pdf [https://perma.cc/5FV4-2Q4T].

259. Steve Jobs, Thoughts on Flash, APPLE (Apr. 2010), http://www.apple.com/ hotnews/thoughts-on-flash/ [http://perma.cc/7F6P-F4YC].

260. Vangie Beal, Mobile Operating Systems (Mobile OS) Explained, WeBOPEDIA (Aug. 10, 2011), http://webopedia.com/DidYouKnow/Hardware_Software/mobile-operatingsystems-mobile-os-explained.html [http://perma.cc/4EQA-BDGR].

261. Mobile Operating System, MEDIABUZZ, http://www.mediabuzz.com.sg/buzz words-aug-10/mobile-operating-system [http://perma.cc/RPU3-A5N9] (last visited Mar. $17,2015)$. 
devices that rely on the Windows Phone OS. ${ }^{262}$ Google thus competes with Apple, Blackberry, Microsoft, and possibly other companies in the market for mobile operating systems.

\section{Google Apps}

Google develops mobile apps. Unlike Android, Google's mobile apps are proprietary. Nonetheless, Google makes most of its core appsincluding Google Search, Google Maps, and YouTube - available to end users free of charge.

Google apps are not only available for a mobile device running on Android, but also might be available on a device that runs on another OS. For example, most Google apps are available on Apple's iPhone,which operates on iOS. A consumer owning any of those devices may simply download Google apps through the app store on his mobile device. On an iPhone, a user may download Google's apps from the Apple App Store. On an Android-operated device, the user will generally use Google Play, the app store offered by Google. Of course, to download non-Google apps for Android-operated devices, a user may also use alternative app stores, such as the Opera Mobile Store and Appland. ${ }^{263}$ This option is generally not available on a device that relies on a proprietary and closed OS, which typically has only one app store available.

The end user has a variety of apps - not only Google apps - from which to choose and download onto his mobile device; some are free, others are not. ${ }^{264}$ In July 2014, Google Play had more than one million apps available to the end user. ${ }^{265}$ Examples of popular apps include Facebook,

262. See Kristin Bent, Samsung Launches First Windows Phone 8 Smartphone, Vows Commitment to Microsoft's OS, CRN (Aug. 30, 2012, 5:07 PM), http://www. crn.com/news/mobility/240006556/samsung-launches-first-windows-phone-8-smartphonevows-commitment-to-microsofts-os.htm [http://perma.cc/EF72-QU8F].

263. Henrik Lewander, Android Application Stores, GiTHub (Nov. 29, 2013), http://github.com/onepf/AppDF/wiki/Android-Application-Stores [http://perma.cc/JW5G-LHC3].

264. See, e.g., Apps and Games, Microsoft, http://windows.microsoft.com/engb/windows-8/apps\#Cat=t1 [http://perma.cc/EN8V-85QP] (last visited Mar. 17, 2015); iTunes Charts, APPLE, http://www.apple.com/itunes/charts/paid-apps/ [http://perma.cc/ AWS9-QB6W] (last visited Aug. 11, 2015); Top Free in Android Apps, GoogLE PLAY, https://play.google.com/store/apps/collection/topselling_free [https://perma.cc/4W3A-WCV3] (last visited Aug. 11, 2015).

265. See, e.g., Number of Android Applications, AppBrain, http://www.appbrain. com/stats/number-of-android-apps [http://perma.cc/24EX-8XCH] (last updated Aug. 11, 2015). 
Pandora Radio, Yahoo Stocks, Instagram, and WhatsApp Messenger. ${ }^{266}$ The fact that a consumer has downloaded Google apps onto his device in no way precludes the consumer from downloading or using an alternative app that provides the same service. Consumers can easily switch from using a Google app to using another app at little or no additional cost. Therefore, to remain attractive for consumers, Google must continuously invest in the development of its mobile apps.

\section{The Google Mobile Services}

GMS is a set of Google apps that one can preload onto a mobile device that runs on Android. GMS includes a variety of Google apps, such as Google Maps, YouTube, Gmail, Google Play, and Google Search. ${ }^{267}$ A manufacturer might decide to preload GMS onto a device so that those apps are available to the consumer immediately when he takes the device out of the box. Google does not charge manufacturers for the right to preload GMS. Google nonetheless requires the manufacturer to enter into a licensing agreement that specifies the conditions for the use of GMS. I analyze those conditions in detail in Part VI.C. ${ }^{268}$

Android and GMS are not interdependent. A manufacturer retains full discretion over whether to use Android on a device and, if so, whether to also obtain a license to preload GMS on that device. Google does not require that a device running on Android come with GMS preloaded. ${ }^{269}$ That is, the manufacturer decides whether or not to obtain a license to preload GMS on its Android devices, and the carrier ultimately decides whether to preload GMS onto these devices. Some manufacturers decide to use Android but not to obtain a license for GMS. For example, Amazon tablets and the Amazon Fire smartphone run on the Android OS but do not use GMS. ${ }^{270}$ Similarly, Nokia X phones operate on Android but are

266. See, e.g., Apps and Games, supra note 264; iTunes Charts, supra note 264; Top Free in Android Apps, supra note 264.

267. Take Google With You, GoOGLE MoBILE, http://www.google.com/mobile/ [http://perma.cc/778E-D6TC] (last visited Aug. 11, 2015).

268. See infra Part VI.C.

269. Alfonso Lamadrid, Some Thoughts on the New Anti-Google (Android) Complaint (Post 3/3): Bundling Allegations, ChILlin'CompeTiTion (Sept. 9, 2013, 5:19 PM), http:// chillingcompetition.com/2013/09/09/some-thoughts-on-the-anti-google-android-complaintpost-33-bundling-allegations/ http://chillingcompetition.com/2013/09/09/some-thoughtson-the-new-anti-google-android-complaint-post-33-bundling-allegations/ [http://perma.cc/ W58Q-AL5Z]; see also Set up Your Android for Google Apps, GoOGLE, https://support.google. com/a/users/answer/1738362?rd=1 [https://perma.cc/L642-4863] (last visited Aug. 11, 2015).

270. Burrows, supra note 23 . 
not preloaded with GMS. Nokia X phones instead come preloaded with other popular apps such as OneDrive and Skype. ${ }^{271}$

Furthermore, hundreds of millions of Android phones manufactured by companies such as Baidu, Tencent, and Xiaomi are sold in China without GMS preloaded. ${ }^{272}$ Although Android is widespread in China, Chinese manufacturers of Android devices preload their own browsers, apps, and app stores. ${ }^{273}$

A manufacturer that decides to use Android but not preload GMS may preload its own core apps or an app suite from another provider than Google. For example, Yandex, a Russian search and software company, unveiled its own mobile app suite in February 2014, which could supplant Google on some devices, including devices running on Android. ${ }^{274} \mathrm{~A}$ manufacturer of devices operating on Android could decide to preload the Yandex mobile suite instead of GMS. Google thus needs to offer appealing apps to persuade manufacturers to preload GMS and not rely on the manufacturers' own apps or those developed by Google's competitors.

In sum, the use of GMS is voluntary. A manufacturer will generally decide to preload GMS only if it believes that the included apps appeal to consumers and will thus increase the value of its mobile device. To stimulate the preloading of GMS, Google hence must offer quality apps that are attractive to end-users.

271. Chris Smith, Nokia X Android Phone Already Hacked to Run Google Apps, Now and Play Store (Mar. 1, 2014), TECHRADAR, http://www.techradar.com/us/news/phone-andcommunications/mobile-phones/nokia-X-android-phone-already-hacked-to-run-googleapps-now-and-play-store-1230002 [http://perma.cc/X45R-SYHY].

272. Kaylene Hong, Report: China Has 270m Android Users - That's Nearly 30\% of Global Android Activations to Date, TNW (Nov. 27, 2013, 2:08 PM), http://thenextweb. com/asia/2013/11/27/report-china-has-270-million-android-users-nearly-30-of-globalandroid-activations-to-date/ [http://perma.cc/S22P-7USU]; Ryan Whitwam, Android Is Failing by Succeeding in China, EXTREMETECH (Dec. 18, 2012, 9:00 AM), http://www. extremetech.com/mobile/143585-android-is-failing-by-succeeding-in-china [http://perma.cc/ HS9B-LTYK]; Baidu Launches Its Own Android-Based Mobile OS in China, Leaves out Google Search and Services, 9To5GoogLE (Sept. 5, 2011), http://9to5google.com/2011/ 09/05/baidu-launches-its-own-android-based-mobile-os-in-china-leaves-out-google-search -and-services/ [http://perma.cc/9KFT-9F58].

273. See, e.g., Baidu Launches Its Own Android-Based Mobile OS in China, Leaves out Google Search and Services, supra note 272.

274. Stephen Shankland, Yandex Suite of Free Android Tools Sidesteps Google, CNET (Feb. 20, 2014, 4:14 AM), http://www.cnet.com/news/yandex-suite-of-freeandroid-tools-sidesteps-google [http://perma.cc/X4NK-N7QN]. 


\section{B. Google's Business Model}

Economic analysis of Google's business model reveals why Google offers Android, Google apps, and GMS free of charge. By offering a wellfunctioning OS and attractive apps, Google can attract users and, by attracting users, promote its mobile advertising business.

\section{How Does Google Monetize Its Free Apps?}

Google operates in a multisided market, which Jean-Charles Rochet and Jean Tirole define as a market "in which one or several platforms enable interactions between end- users, and try to get the two (or multiple) sides 'on board' by appropriately charging each side." 275 Such business models are common. Television networks and newspapers, for example, both generate content to appeal to consumers and thus in turn to advertisers because of the size of their viewership or readership. A video-game console, such as Sony's PlayStation ${ }^{\mathrm{TM}}$ or Microsoft's $\mathrm{Xbox}^{\mathrm{TM}}$, must appeal to both consumers and video-game developers to succeed in the marketplace. ${ }^{276}$ A credit-card issuer such as American Express must persuade consumers to use and merchants to accept its credit card for transactions. ${ }^{277}$ Google's market is similarly composed of a multisided platform: one side of Google's market consists of mobile apps users - typically smartphone and tablet owners - another side consists of advertisers, and still other sides include app developers and mobile device manufacturers. ${ }^{278}$

Google charges different prices to parties on the different sides of the multisided market. ${ }^{279}$ Such a pricing strategy is common in a multisided market. David Evans and Richard Schmalensee have explained that

275. Jean-Charles Rochet \& Jean Tirole, Two-Sided Markets: A Progress Report, 37 RAND J. ECON. 645, 645 (2006). The seminal article on two-sided markets is William Baxter's study of credit cards. See William F. Baxter, Bank Interchange of Transactional Paper: Legal and Economic Perspectives, 26 J.L. \& ECON. 541, 548 (1983).

276. See, e.g., Robert W. Crandall \& J. Gregory Sidak, Video Games: Serious BUSINESS FOR AMERICA'S ECONOMY (2006), https://www.criterioneconomics.com/docs/ sidak-video-games-serious-business-for-americas-economy.pdf [https://perma.cc/QNV78EZS]; André Marchand \& Thorsten Hennig-Thurau, Value Creation in the Video Game Industry: Industry Economics, Consumer Benefits, and Research Opportunities, 27 J. INTERACTIVE MARKETING 141, 142 (2013).

277. See, e.g., James McAndrews \& Zhu Wang, The Economics of Two-Sided Payment Card Markets: Pricing, Adoption and Usage (Fed. Reserve Bank of Richmond, Working Paper No. 12-06, 2012), http://richmondfed.org/publications/research/working _papers/2012/pdf/wp12-06.pdf [http://perma.cc/27XH-3RKR].

278. See Hal R. Varian, The Economics of Internet Search, 96 RIVISTA DI Politica ECONOMICA 9, 11-12 (2006) (explaining Google's market in an article by Google's chief economist).

279. See, e.g., David S. Evans \& Richard Schmalensee, The Industrial Organization of Markets with Two-Sided Platforms, 3 COMPETITION POL'Y INT'L 151, 156 (2007). 
"profit-maximizing prices may entail below-cost pricing to one set of customers over the long run and ... many two-sided platforms charge one side prices that are below marginal cost and are in some cases negative."280 For example, many periodicals do not collect subscription fees from readers but instead rely solely on advertising revenue. Similarly, Google offers its mobile apps free of charge but collects fees from advertisers.

Google's strategy of offering free apps is intended to attract users on the consumer side. ${ }^{281}$ Some Google apps, such as Google Maps and YouTube, are particularly popular. Android and non-Android users have demonstrated their demand for Google apps by choosing to install them even when the apps have not been preloaded on to their devices. For example, in May 2014, Google Maps and YouTube were among the thirty most downloaded apps by users of Apple's iOS devices. ${ }^{282}$ Apple does not preload GMS. The usefulness of the services that Google provides through its apps contributes to the expansion of Google's users. ${ }^{283}$

As any other advertising business would, Google's mobile advertising benefits from a high number of users. Google provides advertisers with both the opportunity to reach its vast number of potential consumers and the ability to target potential customers effectively based on their revealed interests. ${ }^{284}$ For example, when a user of a mobile device submits a query

280. Id. at 151 .

281. See, e.g., Martin Kenney \& Bryan Pon, Structuring the Smartphone Industry: Is the Mobile Internet OS Platform the Key?, 11 J. INDUS. COMPETITION \& TRADE 239, 253 (2011). Kenney and Pon explain that Google's policy of offering Android and Google apps for free is a rational business practice, given Google's business model of selling search-based advertising:

What Google does care about is ensuring that its ads are served on as many mobile devices as possible.... [I]nstead of relying on Android as a direct revenue-generator, Google seems to be currently using it to . . . build the overall market for mobile devices... . To increase the overall market, it makes sense that Google would license Android for free as a way to enable device manufacturers to Id.

design and build quality smartphones quickly and inexpensively.

282. iOS Top App Charts, APP ANNIE (May 1, 2014), http://www.appannie.com/apps/ ios/top/united-states/?device $=$ iphone $\&$ date $=2014-05-01$ [http://perma.cc/4MZC-M6VP].

283. Google Inc., Annual Report (Form 10-K), at 1, 6 (Feb. 11, 2014), https://investor. google.com/pdf/2013_google_annual_report.pdf [https://perma.cc/9XDZ-DX9S] [hereinafter 2013 Google $10-\mathrm{K}$ ] ("We compete to attract and retain users . . . primarily on the basis of the relevance and usefulness of our search results and the features, availability, and ease of use of our products and services.").

284. See Overview, GoOGLE ADWorDS, http://www.google.com/adwords/start [http:// perma.cc/GF2V-X5TM] (last visited Aug. 11, 2015). 
containing a particular keyword on Google Search, Google frequently provides an advertisement associated with that keyword. ${ }^{285}$ When a user clicks on the advertisement, the advertiser pays Google a fee. ${ }^{286}$ In addition to deriving this revenue from Google Search, Google hosts advertisements on other apps, such as YouTube. ${ }^{287}$ Thus, certain Google apps enable Google to generate revenue from advertising.

Advertising revenue allows Google to recoup its investments in the development and maintenance of services that it distributes free of chargeAndroid and Google apps, including GMS ${ }^{288}$ Further, competition compels Google to keep improving its apps and services. If Google's apps become less appealing relative to those of its competitors, Google's user base will shrink, all other factors held constant, which would impair Google's advertising revenue and its profitability as a company. ${ }^{289}$

In sum, Google's practice of offering Android, Google apps, and GMS free of charge is a rational decision, given Google's business model. The large number of consumers that Google's free services attract enables Google to generate profit through mobile advertising. Competition in the app market, coupled with low switching costs, continuously compels Google to offer appealing apps to end-users. A decreased user base would harm Google's advertising business and consequently reduce its profit.

\section{Why Did Google Enter the OS Business?}

Google's strategy of buying Android in 2005 was a logical consequence of the structure of the mobile industry at that time, coupled with Google's interest in the mobile device market. The smartphone represents the convergence of personal computing and mobile telephony. Throughout the 2000s, the boundaries between Google's traditional focus on personal

285. See How it Works, GoogLE ADWords, http://www.google.com/adwords/start/ how-it-works [http://perma.cc/Y6KB-BK5A] (last visited Mar. 14, 2015); Benefits, GOOGLE ADWORDS, http://www.google.com/adwords/start/benefits [http://perma.cc/3WTG55WT] (last visited Aug. 11, 2015); see also Varian, supra note 278, at 11 (explaining the "matchmaker" function of Google). A number of queries (such as "Ebola" or "Syria") trigger no ads because there is no ad inventory associated with those keywords.

286. See How It Works, GOOGLE ADWORDS, supra note 285. For a popular account of the early history of Google's search business, see JOHN BATTELLE, THE SEARCH: HOW Google and Its Rivals Rewrote the Rules of Business AND TRANSFORMED OuR Culture (2005).

287. See 2013 Google $10-\mathrm{K}$, supra note 283 , at 3-4.

288. Id. at 9 .

289. Id. at 6, 8-9. 
computing and the mobile market eroded, and Google sought to enter the mobile business. ${ }^{290}$

In the mid-2000s, Google began offering its first mobile apps, including Gmail and Calendar. ${ }^{291}$ However, the existing conditions in the mobile market did not favor the development of a market for mobile content. The common walled garden business model, in which a firm restricts access to users, limited the development of the mobile ecosystem. ${ }^{292}$ In the early 2000 s, U.S. telecommunications carriers typically kept tight control of apps and content sales over mobile devices. ${ }^{293}$ Carriers opposed mobile features such as Bluetooth and Wi-Fi, which could undermine the carriers' business. ${ }^{294}$ Manufacturers, which depended on mobile carriers to sell their phones, consequently needed to design devices in line with the carriers' requirements. ${ }^{295}$ Similarly, developers complained that carriers did not make available many of the apps expected to attract more app consumers. ${ }^{296}$ As a result, innovation among content providers for mobile devices was limited. ${ }^{297}$ The most widely used mobile app was email, but

290. See, e.g., Thomas W. Hazlett, David Teece \& Leonard Waverman, Walled Garden Rivalry: The Creation of Mobile Network Ecosystems (George Mason Univ. Law \& Econ. Research Paper Series, Paper No. 11-50, 2011), http://ssrn.com/abstract=1963427 [http://perma.cc/Y79S-3N9R].

291. See Our History in Depth, Google, http://www.google.com/about/company/ history/ [http://perma.cc/9YFZ-YQG5] (last visited Aug. 11, 2015).

292. Hazlett et al., supra note 290, at 12; Walter S. Mossberg, Wireless Carriers' Veto over How Phones Work Hampers Innovation, ALLTHINGSD (June 2, 2005, 12:01 AM), http://allthingsd.com/20050602/carriers-veto-hampers-innovation/ [http://perma.cc/3PK9-QYM4].

293. See, e.g., Matthaus Krzykowski, Carriers Begin to Believe in Data Revenue, as Android's Puzzle Pieces Come Together, VentureBeat (Sept. 10, 2008, 10:52 AM), $\mathrm{http}: / /$ venturebeat.com/2008/09/10/carriers-begin-to-believe-in-data-revenue-as-androidspuzzle-pieces-come-together/ [http://perma.cc/23C8-TWZ7]; Timothy Lee, Verizon Wireless Responds to Competitive Pressures by Promising to Open Its Network, TECHDIRT (Nov. 27, 2007, 1:12 PM), https://www.techdirt.com/articles/20071127/130723.shtml [https:// perma. cc/MV5N-LA4P].

294. See, e.g., Lee, supra note 293.

295. See, e.g., Mossberg, supra note 292.

296. See Katie Fehrenbacher, Are Carriers Killing Mobile Innovation?, Gigaom (Apr. 25, 2007, 12:53 PM), http://gigaom.com/2007/04/25/are-carriers-killing-mobileinnovation/ [http://perma.cc/5DZT-HNUD].

297. See Mohit Agrawal, Marginalization-The Biggest Threat to Carriers, TELECOM CIRCLE (Jan. 28, 2009), http://www.telecomcircle.com/2009/01/marginalization-\%E2\% 80\%93-the-biggest-threat-to-carriers// [http://perma.cc/SK65-UMQA]; Mossberg, supra note 292. 
few entertainment options such as music players or games were available. Mobile browsers had trouble displaying web pages designed for PCs. ${ }^{298}$

At the same time, the market for mobile operating systems was fragmented, which made it harder for third-party app developers to achieve economies of scale in writing mobile apps. At first, some manufacturers attempted to develop an OS available for use by more than one manufacturer of smartphones. Nokia and Motorola, together with other manufacturers, developed the Symbian OS. ${ }^{299}$ Palm licensed its OS, PalmSource, to some manufacturers including Sony and Samsung, and Microsoft licensed its Windows CE OS. ${ }^{300}$ Nonetheless, those operating systems quickly became proprietary ventures. Sony Ericsson made proprietary enhancements, called UIQ, to Symbian, and Nokia made others, called S60. ${ }^{301}$ By 2005, the Symbian OS - initially developed by a joint venture including Nokia, Psion, Motorola, and Ericsson-had fragmented into incompatible versions. ${ }^{302}$ Although at that time Symbian had a fifty-one percent share in the market for mobile operating systems, apps developed for one version of the OS did not always run on another version. ${ }^{303}$ Palm reclaimed its right to make proprietary changes to the Palm OS. ${ }^{304}$ Motorola licensed Microsoft's OS and Symbian but also invested in developing its own OS based on Linux. ${ }^{305}$ By 2007, Blackberry and Samsung each used its own proprietary OS. ${ }^{306}$ The fragmentation of operating systems for mobile devices further hampered the development of the market for mobile content.

The situation changed with Apple's entry into the smartphone business. ${ }^{307}$ Apple introduced the first iPhone in June 2007. ${ }^{308}$ Apple offered an even more proprietary system using components of the OS that it had developed for its Macintosh (Mac) personal computer and did not make the OS

298. Joel West \& Michael Mace, Entering a Mature Industry Through INNOVATION: APPLE'S IPHONE STRATEGY 17 (2007), http://www2.druid.dk/conferences/view paper.php?id=1675\&cf=9 [http://perma.cc/58B4-7LSV].

299. Id. at $16-17$.

300. Id.

301. Id. at 17

302. David Gilson, The History of Symbian's Secret Fragmentation, All ABOUT SYMBIAN (Mar. 12, 2012, 3:00 PM), http://www.allaboutsymbian.com/features/item/14405 _The_History_of_Symbians_Secret.php [http://perma.cc/872L-N2MC].

303. Sean Michael Kerner, Report: Symbian at a Mobile Loss, INTERNETNEWS.COM (Feb. 10, 2006), http://www.internetnews.com/wireless/article.php/3584431 [http://perma.cc/ 6U54-3BFZ] (reporting that Symbian had a fifty-one percent market share in 2005, and fifty-six percent in 2004).

304. West \& Mace, supra note 298, at 17.

305. Id.

306. Id. at 35 tbl.4

307. Id. at 2 .

308. Id. 
available for licensing. Apple also used some of its own Mac software, such as the media player and the browser. ${ }^{309}$ The result was a smartphone that more resembled an appliance than a personal computer. ${ }^{310}$ From the standpoint of app sales, Apple's App Store was a dramatic and unexpected advance. ${ }^{311}$ One year after Apple's App Store opened in July 2008, 1.5 billion apps had been downloaded from the Apple App Store for iPhone or iPod Touch devices. ${ }^{312}$ Many third-party developers that sold apps benefited from Apple's platform; because apps attracted users, the developers had some assurance that Apple would manage the platform to support their products. ${ }^{313}$ After Apple's entry into the mobile market, most carriers tried to offer more apps, but some still restricted the use of apps that would cannibalize their core subscription revenues; some carriers limited developers' access to the OS source code because of fear of malware. ${ }^{314}$

Nonetheless, Apple's success with its closed model did not give Google the opportunity it sought to enter the mobile business. Apple's OS was, and as of 2015 still is proprietary, and Apple did not at first allow thirdparty software development for its iPhone-Apple altered this strategy after Google released Android, though Apple kept third-party developers under tight control. ${ }^{315}$ As Hazlett, Teece, and Waverman explain, "[p]articipating in [Apple's] ecosystem requires recognizing Apple's IP and abiding by Apple's rules - access to the Apple App Store requires application developers to grant Apple editorial control, including the right to disapprove of content."316 By relying on Apple's OS, Google would face the risk that Apple could limit future users' access to Google's apps and services and thereby constrain Google's presence in the mobile ecosystem.

309. Id. at 2,35 tbl. 4 .

310. Id. at 6 .

311. Id. at 8-9.

312. Mobile Applications Reach New Milestone: TechWatch Alert, ITU News [hereinafter ITU Milestone], http://www.itu.int/net/itunews/issues/2009/06/04.aspx [http://perma.cc/ TJY4-VWUZ] (last visited Aug. 11, 2015) (describing new app stores and carrier reluctance to allow apps for instant messaging and voice over Internet protocol (VoIP)).

313. Id.

314. Id.

315. See Rob Pegorano, Apple Irks iPhone Developers with App Store Restrictions, WASH. Post (Sept. 29, 2008), http://voices.washingtonpost.com/fasterforward/2008/09/ apple_irks_iphone_developers_w.html [http://perma.cc/MHU8-3QDE].

316. Hazlett et al., supra note 290 , at 9. 
Apple's rapid gains in market share for mobile operating systems spurred others in the mobile market to seek an alternative platform. ${ }^{317}$ However, other OS platforms remained fragmented after Apple's entry. ${ }^{318}$ Nokia struggled to commit to a consistent system for licensing Symbian, and other phone makers were concerned that Nokia would capture most of the value created by Symbian. ${ }^{319}$ Palm's OS had never attracted enough followers to support the development of apps. ${ }^{320}$ RIM's OS was proprietary and RIM was in large part confined to the enterprise market. ${ }^{321}$ Many mobile phone makers and developers seemed unwilling to depend on Microsoft's smartphone OS as a platform owing to Microsoft's history of capturing so much of the value from its Windows platform for personal computers. $^{322}$ Under these circumstances, it was difficult for Google to improve its position in the mobile device business.

Google's development of Android provided an alternative solution to mobile platforms and preluded fast innovation cycles. ${ }^{323}$ Android offered an open platform that enabled app developers and online service providers, including Google, to distribute their apps and services outside walled gardens or proprietary operating systems. With the availability of Android, Google could focus on developing mobile apps and services, without the concern that users would be cut from accessing Google's services by platform owners. The launch of Android provided Google the opportunity it sought to enter the mobile business. Moreover, it provided app developers, device manufacturers, and end-users with a window for feedback, which resulted in fast innovation cycles for Android OS.

317. Brad Stone \& Miguel Helft, Apple's Spat with Google Is Getting Personal, N.Y. TIMES (Mar. 13, 2010), http://www.nytimes.com/2010/03/14/technology/14brawl.html? pagewanted=all [http://perma.cc/W7GD-8PZW].

318. ITU Milestone, supra note 312 ("[A] more smartphones are sold, the creation of mobile applications to run on them is constrained by the fragmentation of the market between different platforms."); Victoria Ho, Mobile Interoperability To Remain Pipe Dream, ZDNET (June 23, 2009, 11:29 AM), http://www.zdnet.com/mobile-interoperability-toremain-pipe-dream-2062055375/ [http://perma.cc/6JZE-4C7W].

319. See Kenney \& Pon, supra note 281, at 251.

320. Id. at $250-51$.

321. Timothy B. Lee, What Killed Blackberry? Employees Started Buying Their Own Devices, WASH. Post (Sept. 20, 2013), http://www.washingtonpost.com/blogs/theswitch/wp/2013/09/20/what-killed-blackberry-employees-started-buying-their-own-devices/ [http://perma.cc/WH3T-TW5X]; BlackBerry OS, GSM Arena, http://www.gsmarena.com/ glossary.php3?term=bb-os [http://perma.cc/8ZW6-CR3H] (last visited Aug. 11, 2015).

322. Hazlett et al., supra note 290, at 11; West \& Mace, supra note 298, at 16-17.

323. Hazlett et al., supra note 290, at 10. Google typically releases a new Android OS every six months. In comparison, Apple releases a new OS only once per year. Mike Isacc, A Deep-Dive Tour of Ice Cream Sandwich with Android's Chief Engineer, ARS TECHNICA (Oct. 21, 2011, 4:58 AM), http://arstechnica.com/gadgets/2011/10/a-deep-divetour-of-ice-cream-sandwich-with-androids-chief-engineer/ [http://perma.cc/E2N2-WZZB]. 


\section{The MADA's Basic Features}

Device manufacturers who adopt the Android OS can separately and optionally choose to obtain a license to preload a suite of proprietary Google apps on their mobile devices. They may preload these apps free of charge, and thus, make them available to consumers at no cost. Mobile carriers ultimately decide which apps to preload on the devices for which the manufacturer has obtained a license at no cost. A manufacturer wishing to preload Google's apps enters into a MADA with Google. Although the MADA is typically confidential, examples of these agreements - the MADAs into which Google entered with HTC and Samsung, respectively-became publicly available during the Oracle v. Google litigation and provide a general understanding of the conditions under which Google licenses its proprietary mobile apps. ${ }^{324}$

First, the MADAs into which Google entered with HTC and Samsung specify that if the manufacturer chooses to preload GMS on a device, it shall preload the complete GMS suite-with the exception of certain optional apps - on to the device. ${ }^{325}$ In the contracts with HTC and Samsung, the apps that Google offered together in GMS included Gmail, Google Talk, YouTube, Google Maps, Google Calendar, Contact Sync, Android Market Client (the predecessor of Google Play), Network Location Provider, and Google Phone-top Search - the app that provides access to Google Search engine. ${ }^{326}$ In other words, the manufacturer opting to preload Google apps offered in GMS may not cherry-pick whatever Google apps it wishes to preload on to a mobile device. Rather, Google allows the manufacturer to preload Google's apps on the condition that it preloads GMS as defined in the MADA - except for the specified optional apps.

324. Oracle Am., Inc. v. Google Inc., 872 F. Supp. 2d 974 (N.D. Cal. 2012); see, e.g., Ina Fried, A Look at Google's Not-Always-Secret Contracts with Android Phone Makers, $<$ RE/CODE $>$ (May 3, 2014, 12:25 PM), http://recode.net/2014/05/03/a-look-at-googles-notalways-secret-contracts-with-android-phone-makers/ [http://perma.cc/DQ8Q-Q2ZU] (describing the circumstances under which the MADAs were made public).

325. See, e.g., Mobile Application Distribution Agreement (Android) Between Google Inc. and HTC Corporation $\S 2.1$ (Jan. 1, 2011) [hereinafter Google-HTC MADA] $\mathrm{http}: / / \mathrm{www}$. benedelman.org/docs/htc-mada.pdf [http://perma.cc/8ND2-FZLQ] (discussing the terms of the license grant); Mobile Application Distribution Agreement (Android) Between Google Inc. and Samsung Electronics Co., Ltd. § 2.1. (Jan. 1, 2011) [hereinafter Google-Samsung MADA] http://www.benedelman.org/docs/samsung-mada.pdf [http://perma. cc/EEH7-N48W]. See also id. § 1.15 (listing Orkut, Google Goggles, Google Earth, Finance, News \& Weather, Google Buzz, and Google Voice as optional Google applications).

326. See, e.g., Google-HTC MADA, supra note $325, \S 1.11$ 
Second, the MADAs entered with HTC and Samsung allow the manufacturer to decide on which devices it chooses to preload GMS. ${ }^{327}$ That is, the manufacturer has full discretion to install GMS on all, some, or none of its devices, leaving it free to decide the volume of devices that come with or without GMS. ${ }^{328}$

Third, both MADAs specify the location of GMS apps on the mobile device's screen. In particular, the MADAs with HTC and Samsung specify that Google Phone-top Search and the Android Market Client Icon shall be placed "at least on the panel immediately adjacent to the Default Home Screen" 329 - that is, the screen adjacent to the screen that appears before the user scrolls to the home screen in any direction. ${ }^{330}$ All other Google apps of GMS shall appear no more than one level below the "Phone-top," 331 which is defined to be the top-most level of screen from which the user can launch apps. ${ }^{332}$ In addition, the manufacturer shall set Google Phone-top Search as the default search provider for all web search points on the device. ${ }^{333}$

Fourth, a manufacturer wanting to preinstall GMS on its devices shall make the devices "Android compatible," which requires that the "final software build on Devices must pass the Compatibility Test Suite" before

327. Google-Samsung MADA, supra note $325, \S 2.4$ ("For the sake of clarity, Company has no obligation to install the Google Applications on all of its devices.").

328. The MADAs also do not prevent a manufacturer from preloading on the device other apps besides GMS. Google-HTC MADA, supra note 325, § 2.6 ("Open Devices. The parties will create an open environment for the Devices by making all Android Products and Android Application Programming Interfaces available and open on the Devices and will take no action to limit or restrict the Android platform."). In other words, even if the manufacturer preloads GMS on a device, it remains free to also preload any other competitive apps on that device. See id. $\S \S 2.6,3.4$; Mike Heuer, Monopoly? Google Says App Deals Spur Market, Courthouse News Serv. (July 16, 2014, 5:42 AM), http://www.courthousenews.com/2014/07/16/69553.htm [http://perma.cc/TAC7-A3AP] ("Manufacturers are free to load rival search engines and other apps ...."). In addition, MADAs do not prevent users from downloading competing apps. To the contrary, the inclusion of Google Play in GMS increases the availability of competing apps. See David O'Connor, Observations on the Economics of Mobile App Suite Bundling, DisCo (Mar. 3, 2014), http://www.project-disco.org/competition/030314-observations-on-the-economicsof-mobile-app-suite-bundling/ [http://perma.cc/43J8-6HPY].

329. See Google-HTC MADA, supra note 325, § 3.4; Google-Samsung MADA, supra note $325, \S 3.4$.

330. Google-HTC MADA, supra note 325, § 1.7; Google-Samsung MADA, supra note $325, \S 1.8$.

331. Google-HTC MADA, supra note 325, § 3.4; Google-Samsung MADA, supra note $325, \S 3.4$.

332. See Google-HTC MADA, supra note $325, \S 1.16$.

333. Id. $\S 3.4$. 
the device is launched. ${ }^{334}$ As I discuss later, this aspect of the MADA aims to prevent platform fragmentation.

Finally, both MADAs recognize that the "Telecom Operator customer" - the carrier, such as AT\&T or Verizon Wireless - might impose on a manufacturer different requirements with respect to the location of Google apps on the phone's screen than the one specified in the MADA. ${ }^{335}$ Although the MADA acknowledges that such changes are possible, it specifies that they may be made only with Google's explicit written approval. ${ }^{336}$

\section{Google's Reasons for Offering GMS Subject to the MADA's Restrictions}

Google has three compelling business justifications for offering its free apps on the conditions specified in a MADA. First, the MADA encourages manufacturers to prevent Android's fragmentation. Second, the MADA enables Android-operated devices to meet consumer expectations by ensuring an out of the box experience comparable to the experience that other mobile devices offer. Third, the MADA's requirements enable Google to counteract free riding and cherry-picking. Google's achievement of these three goals promotes Android's competitiveness and the availability of an open mobile platform that provides Google, and other app developers, unrestricted access to the mobile industry.

\section{Countering Intra-Platform Fragmentation}

The MADA between Google and the mobile manufacturer addresses the risk of Android's fragmentation. Fragmentation occurs when individuals modify a platform's source code to produce multiple versions of the platform. ${ }^{337}$ As other individuals add compounded modifications to these

334. Id. § 2.7; Google-Samsung MADA, supra note $325, \S 2.7$.

335. Google-HTC MADA, supra note 325, § 4.8; Google-Samsung MADA, supra note $325, \S 4.8$

336. Google-HTC MADA, supra note 325, § 4.8; Google-Samsung MADA, supra note $325, \S 4.8$

337. See, e.g., Mona Erfani Joorabchi, Ali Mesbah \& Philippe Krutchen, Real Challenges in Mobile App Development 3 (2013) (unpublished manuscript), http://www. ece.ubc.ca/ amesbah/docs/mona-esem13.pdf [http://perma.cc/TR3X-MKL7] ("On the same platform, various devices exist with different properties such as memory, CPU speed, and graphical resolution. There is also a fragmentation possible on the [OS] level. A famous example is the fragmentation on Android devices with different screen sizes and resolutions.”). 
already modified versions, the multiple versions of the platform become incompatible. ${ }^{338}$ As a result, software and apps designed for one version of a platform can no longer run on another fragment of the same OS platform. Fragmentation is one risk of open-source platforms, such as Android. ${ }^{339}$ Anyone may freely modify and customize the Android OS, but such modifications and customizations may produce divergences between different versions of the OS that hinder cross-compatibility between Android-operated devices. ${ }^{340}$ The MADAs do not prohibit customization by OEMs so long as they do not cause incompatibility. In other words, Google's open-source model permits customization and product differentiation with respect to a device's look and feel, as reflected in the hundreds of different Android devices available today. The MADAs do not bar customization; rather, they seek to encourage compatibility. A closed OS does not face similar risks of fragmentation. Each version of Apple's iOS is practiced only by the iPhone, iPod, and iPad - each of which has more uniform hardware specifications and software modifications compared with a typical mobile device running on an open-source OS. ${ }^{341}$ Users and manufacturers may not modify the code of iOS. Consequently, Apple's iOS does not face the same risk of fragmentation as Android. ${ }^{342}$

Android's fragmentation would have several negative consequences. Fragmentation might cause the malfunctioning of mobile apps and thus degrade the quality of the consumer experience. Fragmentation would also harm the development of apps for Android-operated devices. As fragmentation worsens, the cost of developing and maintaining apps for divergent versions of Android rises. ${ }^{343}$ If an app could run on only one

338. See Steven Weber, The Success of Open Source 12 (2004).

339. See Philip Elmer-DeWitt, Fragmentation Blues: Google's Android vs. Apple's iOS, ForTUNE (Dec. 13, 2013, 4:18 PM), http://fortune.com/2013/12/12/fragmentationblues-googles-android-vs-apples-ios/ [http://perma.cc/5YUF-5P79]; Martyn Williams, Google Targets Android Fragmentation with Updated Terms for SDK, TECHHIVE (Nov. 15, 2012, 10:15 AM), http://www.techhive.com/article/2014089/google-targets-androidfragmentation-with-updated-terms-for-sdk.html [http://perma.cc/A5ZB-KS5D]; see also Fabrizio Capobianco, Android: Fragmentation Is Innovation, but It Could Kill You, TV IS SOC., AGAIN (Mar. 29, 2010), http://www.fabcapo.com/2010/03/android-fragmentationis-innovation-bit.html [http://perma.cc/U8RU-WWEM].

340. See, e.g., Licenses, ANDROID, http://source.android.com/source/licenses.html [http://perma.cc/KN8R-AKMG] (last visited July 31, 2015); The Open Source Definition (Annotated), OPEN SOURCE INITIATIVE, http://opensource.org/osd-annotated [http://perma.cc/ 55AF-DU4S] (last visited July 31, 2015)

341. See, e.g., Zach Epstein, Android Fragmentation vs. iOS Fragmentation, BGR (Dec. 13, 2013, 12:10 PM), http://bgr.com/2013/12/13/android-fragmentation-vs-iosfragmentation [http://perma.cc/335G-6NZG].

342. Id.

343. See Philip Elmer-Dewitt, Android Is a Mess, Say Developers, Fortune (Apr. 4, 2011，3:51 PM), http://tech.fortune.cnn.com/2011/04/04/android-is-a-mess-say-developers 
version of Android, the potential user base for that app would be limited to the users of that specific version. The limited number of users might not provide sufficient economies of scale to motivate developers to create apps for Android. ${ }^{344}$ Consequently, the fragmentation of the Android OS would jeopardize its appeal to app developers. The resulting decline in the creation of Android apps would in turn threaten Android's appeal to consumers, because the availability of a wide variety of apps stimulates consumer demand for a particular mobile device. The demand for Android devices would fall if all other factors remain constant.

Google encourages the continued compatibility of different releases of Android by offering GMS free of charge under the MADA, which in turn requires manufacturers to agree to take steps to reduce the risk of fragmentation. ${ }^{345}$ Each mobile device covered by the MADA shall pass a test for Android compatibility - the Compatibility Testing Suite (CTS). ${ }^{346}$ The CTS ensures that a device meets basic specifications to ensure crosscompatibility across all Android devices. ${ }^{347}$ In addition, the MADA requires the manufacturer to avoid an action that might "cause or result in the fragmentation of Android." 348 If a manufacturer agrees to make its devices Android-compatible, Google will allow the manufacturer to preload GMS free of charge. In other words, the MADA provides an incentive for manufacturers to take steps that decrease the risk of Android's fragmentation.

[http://perma.cc/JX2E-CEDU]; see also Priya Ganapati, Top Android Champions Fire Back at Steve Jobs, CNN (Oct. 19, 2010, 5:02 PM), http://www.cnn.com/2010/TECH/mobile/ 10/19/android.jobs.response/index.html?_s=PM:TECH [http://perma.cc/LC7N-NQ8U] (quoting Steve Jobs' explanation of why developers would prefer iOS to Android: "We also think our developers can be more innovative if they can target a singular platform rather than 100 variants. They can put their time into innovative new features rather than testing on hundreds of different handsets ...."); Poornima Gupta, Apple's Schiller Blasts Android, Samsung on Galaxy's Eve, ReUTERS (Mar. 13, 2013, 8:23 PM), http://www.reuters.com/ article/2013/03/14/us-apple-schiller-idUSBRE92C1FQ20130314 [http://perma.cc/FF5UM2C6] (reporting Apple senior vice president of worldwide marketing Phil Schiller's criticism of Android's fragmentation problem).

344. See Elmer-Dewitt, supra note 343.

345. See, e.g., Google-Samsung MADA, supra note $325, \S 2.7$.

346. Id.

347. Android Interfaces, ANDROID, https://source.android.com/devices/ [https://perma. cc/S3GR-692Z] (last visited Feb. 25, 2015.)

348. Google-Samsung MADA, supra note $325, \S 2.2$. 
In sum, the MADA's requirements help Google to avoid fragmentation and thereby maintain the appeal to end users of Android-operated devices that use GMS.

\section{Meeting Consumer Expectations}

The MADA's conditions on distribution of GMS enable Androidoperated devices to meet consumer expectations. The vast majority of mobile devices reach the end user with a set of preinstalled apps that offer the consistent out of the box experience that consumers demand. ${ }^{349}$ The Windows Phone comes with Office and Bing apps preinstalled on the device at no additional charge. ${ }^{350}$ Apple's iPhone and iPad come with free preloaded apps, such as Calendar, Maps, Video, iPhoto, and iTunes. ${ }^{351}$ Apple's decision to offer this set of preinstalled apps at no additional charge comports with the perception that consumers value a consistent out of the box experience when purchasing a mobile device. The distinctive set of apps preinstalled on each mobile device contributes to a recognizable out of the box experience that consumers expect when buying the mobile device.

Where a device manufacturer chooses to preload GMS on its Androidoperated device, the MADA's requirement that the manufacturer preload all apps in GMS is intended to meet the consumer's expectation that certain functions will be available out of the box. This requirement enables Android-operated devices with GMS to offer an experience

349. See, e.g., Access Yahoo Mail on Mobile Devices, YAHoo!, https://help.yahoo. $\mathrm{com} / \mathrm{kb} / \mathrm{mail} /$ access-yahoo-mail-mobile-devices-sln8223.html?impressions=true [https:// perma.cc/5FRX-54Q8] (last visited Feb. 25, 2015); Manage Apps: BlackBerry Z10, TMOBILE, http://support.t-mobile.com/docs/DOC-6103\#preinstalled_apps [http://perma.cc/ CAG8-A3XY] (last visited Feb. 25, 2015); Common Questions: Getting Started, HTC, http://www.htc.com/us/support/htc-one-vx-att/faq/1/ (last visited Feb. 25, 2015); see also O'Connor, supra note 328 ("Google presumably seeks to offer its customers a consistent, integrated experience available to users 'out of the box' across different Android devices built by different Android manufacturers."); What Apps Come with / Are Pre-Installed on the iPad?, IPAD GUIDE, http://www.theipadguide.com/faq/what-apps-come-are-pre-installed -ipad [http://perma.cc/TZR2-4GQL] (last visited Aug. 11, 2015).

350. What's New in Windows Phone 8.1, WINDOws PHONE, http://www.windowsphone. com/en-us/how-to/wp8/basics/whats-new-in-windows-phone [http://perma.cc/DNT4-7TK3] (last visited Aug. 11, 2015); Mihaita Bamburic, 10 Reasons why You Should Consider Windows Phone, BETANEWs, http://betanews.com/2013/10/21/10-reasons-why-you-should-considerwindows-phone/ [http://perma.cc/YQ2C-PNFL] (last visited Aug. 11, 2015).

351. iPhone $5 \mathrm{~s}$, APPLE, https://www.apple.com/iphone-5s/built-in-apps/ [https://perma.cc/ 6MXR-T686] (last visited Feb. 25, 2015); Apple Makes iWork, iPhoto and iMovie Free with New iOS Devices, APPLE INSIDER (Sept. 10, 2013, 10:25 AM), http://appleinsider. com/articles/13/09/10/apple-makes-iwork-iphoto-and-imovie-free-with-new-ios-devices [http://perma.cc/5PFV-73CT]; What Apps Come with/Are Pre-Installed on the iPad?, supra note 349 
comparable to the experience provided by devices that rely on other operating systems. The MADA thus ensures that Android-operated devices, including GMS, will remain competitive and appealing to consumers.

\section{Avoiding Free Riding and Cherry-Picking}

The MADA enables Google to prevent free riding by its competitors. Free riding occurs when a firm takes advantage of a product or service produced by another firm without compensating the latter firm for the costs of providing the product or service. ${ }^{352}$ When a provider does not obtain adequate compensation for its product or service because of free riding, its incentive to provide that product or service decreases. The Supreme Court has long recognized this principle in its antitrust jurisprudence. ${ }^{353}$ In the economic literature, scholars recognize that the inability to prevent free riding leads to a socially suboptimal level of investment. ${ }^{354}$

To generate revenues, Google needs to attract consumers. Google is interested in having its apps preloaded on to mobile devices. If a manufacturer preloads Google's apps, the apps are exposed to a larger number of users. If those apps are attractive, users are more likely to use them, instead of ignoring them, and Google consequently has the potential to earn higher revenues. However, manufacturers will decide to preload GMS only if it includes apps that appeal to consumers. For this reason, Google needs to invest in the development and maintenance of apps that will appeal to consumers.

The development of appealing apps might nonetheless be costly. One example is Google Play, which did not generate significant revenues in its first years. Google incurred the costs of developing and maintaining the store, but the store itself did not initially generate significant revenues for Google. In 2010, Google projected that the sales revenue generated through Google Play would be only $\$ 14.5$ million in 2011, \$35.9 million in 2012, and $\$ 64.8$ million in $2013 .^{355}$ This revenue was divided among

352. See, e.g., Hal R. VArian, Microeconomic Analysis 417 (3d ed. 1992).

353. See Continental T.V., Inc. v. GTE Sylvania Inc., 433 U.S. 36, 55 (1977) (discussing the free rider problem).

354. See, e.g., Robert S. Pindyck \& DANiel L. Rubinfeld, Microeconomics 668 (6th ed. 2005).

355. Google's Slides on Android Quarterly Report in the Oracle Patent Case, THE VERGE (Apr. 25, 2012, 2:40 PM) [hereinafter Google's Slides], http://www.theverge. com/2012/4/25/2974772/googles-slides-on-android-quarterly-report-in-the-oracle-patent- 
different stakeholders, including app developers and carriers, and Google reportedly retains about five percent of the generated revenue. ${ }^{356}$ In comparison, Google's target revenues from the distribution of ads though Android were \$492.8 million in 2011, \$804.3 million in 2012, and \$1.27 billion in 2013. ${ }^{357}$ Nonetheless, Google's investments in Google Play made economic sense. A reliable and well-maintained app store is essential to the performance of the mobile platform and, consequently, to the appeal of Android-operated devices that use GMS.

Free riding on Google apps would undermine Google's ability to recoup its investments. Permitting mobile device manufacturers to cherry-pick Google apps - by preloading only those apps from GMS that are not monetized and refusing to preload others-would enable the manufacturer to attract a larger user base by free riding on preloaded Google apps that the manufacturer obtained free of charge. A competitor that free rides on Google apps would undermine Google's ability to recoup its investments and would decrease Google's incentives to invest in developing and maintaining free apps. Consequently, Google might invest a suboptimal amount in new product development. ${ }^{358}$

The MADA counteracts the free rider problem. Google's contractual strategy to avoid free riding is familiar and conventional. Vertical restrictions address free riding by competing producers. ${ }^{359}$ Producers rely on retailers for the distribution of goods and provide those retailers with special services that enhance the appeal of those retailers to consumers. For example, suppose that a producer distributes its product through a franchise network. Besides supplying the franchisee with the product, the franchisor typically gives the franchisee equipment, educates the

case [http://perma.cc/8T3G-9CZU] (showing a slide presentation used as trial exhibit in Oracle Am., Inc. v. Google Inc., No. 3:10-cv-03561-WHA (N.D. Cal. July 12, 2010)).

356. Id. According to Peter Oppenheimer, Apple's senior vice president and chief financial officer, even Apple - which, unlike Google, retains thirty percent of its app revenues - runs its App Store "just a little over breakeven." Bryan Chaffin, Apple: App Store Runs Just Above Break Even, MAC OBSERVER (Feb. 23, 2011, 7:04 PM), http://www. macobserver.com/tmo/article/apple_app_store_runs_just_above_break_even [http://perma.cc/ A5TG-6FAY].

357. Google's Slides, supra note 355.

358. See Ilya R. Segal \& Michael D. Whinston, Exclusive Contracts and Protection of Investments, 31 RAND J. ECON. 603, 619, 628 (2000). See also Howard P. Marvel, Exclusive Dealing, 25 J.L. \& ECON. 1, 7-8 (1982) (explaining how a dealer may take advantage of a manufacturer's promotional investment by selling a rival manufacturer's product).

359. See, e.g., Dennis W. Carlton \& Jeffrey M. Perloff, Modern Industrial ORGANIZATION 424-25 (4th ed. 2005). Another way to remedy free riding is vertical integration. Apple, a vertically integrated company, produces an OS, an app store, and handsets and operates retail outlets for its products. See, e.g., ATKEARNEY, SMARTER PHONES, SMARTER Moves 3 (2012), http://www.atkearney.com/documents/10192/0f76a 23b-e809-472c-8819-b5676e02d250 [http://perma.cc/4FA8-R54Z]. 
franchisee's personnel, or pays (and provides instructions) for advertising. To prevent competing producers from free riding, the franchisor may require exclusive contracts or preferential placement of the franchisor's products. The economic literature recognizes the efficiency of such vertical restrictions, which increase competition for the distribution channels. ${ }^{360}$

Google's MADA achieves a similar solution. Without the MADA's restrictions, competitors could free ride on the user base that Google had attracted by offering free apps. Handset manufacturers, for example, could preload only a select subset of non-monetized GMS apps, allowing Google's competitors to profit freely from Google's investment. The MADA's requirements aim to prevent competitors from free riding on Google's free distribution of its apps.

\section{DO THE MADA’S REQUIREMENTS UNLAWFULLY RESTRAIN TRADE?}

Some allege that the MADA's requirements are unlawful restraints of trade. These allegations are not convincing. The MADA's requirements are lawful under the Supreme Court's precedents on tying and under the D.C. Circuit's rule of reason analysis for software integration. The MADA's requirements benefit consumers. The MADA's requirements do not restrict competition in general and mobile search.

\section{A. Allegations that the MADA's Restrictions Are Unlawful}

In April 2013, FairSearch filed a complaint with the European Commission challenging Google's licensing practice for apps. FairSearch reportedly alleged that Google's practices of offering a bundle of free apps and requiring their premium placements on the mobile device screen harm competition. A press release stated:

Android phone makers who want to include must-have Google apps such as Maps, YouTube or Play are required to pre-load an entire suite of Google mobile services and to give them prominent default placement on the phone, the complaint says. This disadvantages other providers, and puts Google's Android in control of consumer data on a majority of smartphones shipped today. 361

360. See, e.g., Benjamin Klein, Exclusive Dealing as Competition for Distribution "on the Merits," 12 GEO. MASON L. ReV. 119, 161 (2003).

361. FairSearch Announces Complaint in EU on Google's Anti-Competitive Mobile Strategy, supra note 12. 
On April 15, 2015, the European Commission announced that it has opened formal proceedings against Google to investigate "if the company's conduct in relation to its Android mobile operating system as well as applications and services for smartphones and tablets has breached EU antitrust rules." $" 362$

In May 2014, lawyers filed an antitrust class action complaint presenting similar arguments before the U.S. District Court for the Northern District of California. ${ }^{363}$ The complaint — amended in August 2014 - alleged that Google is a monopolist in the "U.S. market for general search" in the United States-described as search "on all devices including laptops, desktops, mobile phones, and tablets" - as well as "a monopolist in the U.S. market for handheld general search." 364 The MADA allegedly allows Google to "maintain and extend" its monopoly in the "general search" and "handheld general search" markets. ${ }^{365}$ The plaintiffs voluntarily dismissed the complaint less than one year after they made their initial allegations. ${ }^{366}$ The allegations and main arguments in the amended complaint were as follows.

First, some apps within GMS, such as YouTube or Google Play, are allegedly essential to the marketability of an Android-operated device, because "customers expect to see these apps on their Android Devices." 367 If a manufacturer wishes to preload one of the popular Google apps, it can preload GMS as a suite of apps under the condition to give specific apps premium placement on the device screen.

Second, "[w]ithout paying Android OS manufacturers for the privilege," Google allegedly uses the MADA to compel manufacturers to confer to Google Phone-top Search the position of default search engine. ${ }^{368}$ The MADA requires the manufacturer to set Google Phone-top Search "as the default search provider for all Web search access points." 369 Obtaining the default status is allegedly "by far the more cost-efficient and effective way for any search engine company to distribute its product." ${ }^{\text {"370 }}$ Although competitors could convince consumers to download the competing search application on their devices and MADAs facilitate such downloading by including Google Play in GMS, the persuasion process would allegedly

362. Press Release, Commission Sends Statement of Objections to Google, supra note 5 .

363. Class Action Complaint, supra note 13, at 1.

364. First Amended Class Action Complaint, supra note 14, at 7-8.

365. Id. at 4 .

366. Plaintiffs' Notice of Voluntary Dismissal, supra note 19.

367. First Amended Class Action Complaint, supra note 14, at 3.

368. Id. at 21 .

369. Id. at 3 (quoting Google-HTC MADA, supra note $325, \S 3.4$ ).

370. Id. at 21 . 
require competitors to "undertake an expensive advertising campaign."371 Further, although competitors could educate consumers how to change the search engine on their devices, this process allegedly "requires significant effort on the part of the consumer," and most users would allegedly not change a device's default search engine. ${ }^{372}$ Competitors willing to compete in the market for mobile search would thus allegedly need to invest "tremendous resources into marketing and advertising to gain a relatively small number of users." $" 373$

Third, the amended complaint scrutinized Google's contract with Apple - the "largest non-Android phone manufacturer." 374 Under the terms of that allegedly exclusionary agreement, Google pays Apple for Google "to act as the default search engine on Apple iPhones, iPads, and iPods." "375 Because the Google Search engine allegedly occupies a key position on every mobile device currently available on the market, Google allegedly has prevented competitors from entering the handheld search market. ${ }^{376}$

By supposedly dictating that the vast majority of mobile device searches will use Google's search engine, the MADAs are allegedly "designed to maintain and extend Google's monopolies in general search and handheld general search." 377 There is allegedly "no lawful, pro-competitive reason for Google to condition licenses to pre-load popular Google apps on making its search product the default search engine on covered devices." 378 By imposing this licensing condition, Google allegedly suppresses competition and harms consumers by "robbing" them of choice, reducing innovation, and increasing the prices of mobile devices to a level "[higher] than they would be if Google did not foreclose competition." 379 Google's licensing practices allegedly exclude actual competition and restrain prospective competition in search markets. ${ }^{380}$ If a manufacturer could choose a default search engine for its devices, the amended complaint alleged that the quality of Internet search would improve. ${ }^{381}$ Further, if manufacturers

$\begin{array}{ll}\text { 371. } & \text { Id. } \text { at } 21-23 . \\ 372 . & \text { Id. } \text { at } 23 . \\ 373 . & \text { Id. } \text { at } 23 . \\ 374 . & \text { Id. } \text { at } 20 . \\ 375 . & \text { Id. } \text { at } 20 . \\ 376 . & \text { Id. } \text { at } 20-21 . \\ 377 . & \text { Id. } \text { at } 4 . \\ 378 . & \text { Id. } \text { at } 4 . \\ 379 . & \text { Id. } \text { at } 29 . \\ 380 . & \text { Id. } \text { at } 28 . \\ 381 . & \text { Id. } \text { at } 4 .\end{array}$


were free to choose a default search engine other than Google, Google's rivals would allegedly compete for the default status, by "offering to pay device manufacturers for that status on various Android smartphones and tablets." ${ }^{382}$ Google's licensing practices thus allegedly harm consumers by inflating prices of mobile devices, which, in the counterfactual world, would supposedly decrease due to increased competition for default engine status. ${ }^{383}$

\section{B. The Failure of the Prima Facie Case}

The original antitrust class action complaint against Google alleged that the MADA's requirements establish an unlawful tying arrangement. This allegation simplistically assumed the answer to the central question under the Supreme Court's jurisprudence on tying: is GMS a bundle of separate products or is it a single product? To presume that GMS is an aggregation of separate products is to ignore the dynamic nature of the mobile app market. The complainants in the class action case seem to have implicitly recognized the incredibility of a tying claim, as they abandoned such claim in their amended complaint.

Although Google offers its apps individually to end users, the apps offered together in a mobile suite may be collectively viewed as a distinct, individual product. One can evaluate the question whether GMS constitutes an individual product from both demand-side and supply-side perspectives. From a demand-side perspective, it is far from clear that GMS is an aggregation of individual apps rather than a single product. Some manufacturers of mobile devices might prefer to acquire and preload a mobile suite, rather than obtain each app individually, given that licensing an entire suite rather than individual apps may significantly decrease search and transaction costs. ${ }^{384}$ As I explained earlier, Yandex began offering its mobile suite to manufacturers as an alternative to GMS. 385 Yandex's offer demonstrates that there is demand for a mobile suite as an individual product, rather than as separate apps. One could reasonably argue that, by offering its apps as part of a suite of apps, Google created an entirely new market in which companies compete by offering alternative mobile app suites. From this perspective, the mobile app suite is not a suite of individual products, but rather a single product.

382. Id.

383. Id. at 30 .

384. See, e.g., 9 AREEDA \& HovENKAMP, supra note 45, व 1703g2 (“'[S]elling two items together can serve the convenience and thus increase the use by consumers or can reduce their costs or those of the tying defendant.... [L]owering costs or raising value tends to move ... use closer to perfectly competitive levels.").

385. See supra Part VI.A.3. 
GMS might also be considered a single product from a supply-side perspective. A combination of products should be considered a single product if it is economically inefficient to sell the combined products separately. ${ }^{386}$ Distributing GMS to manufacturers of mobile devices as a suite of apps is central to Google's business model. If it did not offer its apps as part of a larger whole, Google might not have the economic incentive and ability to provide certain mobile apps free of charge. Development of highly advanced apps such as Google Maps might not be cost-justified for Google if it could not combine those apps in a package for preinstallation by manufacturers. Therefore, for purposes of antitrust analysis, the efficiencies resulting from Google's combined offering of apps in GMS suggest that GMS is a single product rather than a bundle of separate products.

One can reasonably argue that, for antitrust purposes, GMS is an individual product. The absence of two distinct products - an essential element of tying - ends the antitrust inquiry. ${ }^{387}$

With respect to the MADA's requirements, another missing element of the prima facie case for per se unlawful tying is the possession of market power over the tying product. This proposition might sound surprising, given that Google has a commanding position in Internet search. But the pleading requirements in an antitrust case are rigorous, ${ }^{388}$ and the California class action complaint did not clearly define what constitutes either the tying product or the tied product under the MADA. The amended complaint alleged that Google has market power in handheld search and general search, but it does not allege that Google Search is the tying product. ${ }^{389}$ Rather, the amended complaint alleged that "Google [is] conditioning access to their applications on making Google the default search engine." 390 The amended complaint thus implied that Google ties its search app and other less popular apps to two apps-YouTube and Google Play. ${ }^{391}$ The amended complaint nonetheless failed to allege, let alone prove, that Google possesses market power with respect to the market in which either

386. AREEDA \& HOVENKAMP, supra note 45, at 168 ("That bundling is required to sell the items at all certainly proves a single product.").

387. See Jefferson Par. Hosp. Dist. No. 2 v. Hyde, 466 U.S. 2, 9-18 (1984).

388. See generally Bell Atlantic Corp. v. Twombly, 550 U.S. 544 (2007) (interpreting the well-pleaded complaint in an antitrust context).

389. See First Amended Class Action Complaint, supra note 14, at 7-8.

390. Id. at 19

391. Id. at $13-15$. 
YouTube or Google Play competes. ${ }^{392}$ The amended complaint merely alleged that YouTube and Google Play are very "popular Google apps,"393 but it does not allege that Google has market power over the services provided by either of the two apps. ${ }^{394}$ It is questionable whether Google in fact has significant market power in the market where those apps compete. An article published in August 2014 in The Wall Street Journal, summarizing the results of ComScore's annual U.S. Mobile App Report, reported that the apps more frequently used by consumers are Facebook, Pandora Radio, and Instagram. ${ }^{395}$ Therefore, there is no clear evidence that Google has market power in any allegedly tying product market.

More fundamentally, the whole reason that the possession of market power is relevant to the prima facie case for per se unlawful tying is because the defendant is also alleged to have exploited that market power through the specific means of forcing the consumer to pay for some other product that the consumer does not want. ${ }^{396}$ How, then, as a matter of antitrust law is it ever meaningful to say that a consumer has been forced to receive for free an extra, convenient feature in a product? Even the consumer who prefers another mobile app is free at all times to take or leave the apps included in GMS, just as the sports fan who subscribes to the Sunday New York Times is free to keep or discard the New York Times Book Review.

Google's product integration gives the consumer a real option in the precise economic sense of the term, and a real option plainly gives value to its holder, as is widely understood in the theory of finance. ${ }^{397}$ Any real option subsumes within it the option to decline the offer. ${ }^{398}$ It would be frivolous to say that some tenet of antitrust law requires that a consumer

392. Id.

393. Id. at 13

394. See id. at 3.

395. Daisuke Wakabayashi, The App Enigma: Users Love 'Em but They Don't Download New Ones, Wall ST. J. (Aug. 22, 2014), http://blogs.wsj.com/digits/2014/08/ 22/the-app-enigma-users-love-em-but-they-dont-download-new-ones/?mod=Tech_newsreel_3 [http://perma.cc/4UVV-LHRF]

396. Jefferson Par. Hosp. Dist. No. 2 v. Hyde, 466 U.S. 2, 27 (1984).

397. For discussions of real options to use assets that embody sunk costs, see AVINASH K. Dixit \& ROBERT S. PINDYCK, INVESTMENT UNDER UNCERTAINTY 8, 11 (1994); Jerry Hausman, Valuing the Effect of Regulation on New Services in Telecommunications, in Brookings Papers on ECONOMiC ACTIVITY: Microeconomics 1997, at 1, 27 (Martin Neal Baily et al. eds., 1998); Jerry A. Hausman \& J. Gregory Sidak, A Consumer-Welfare Approach to the Mandatory Unbundling of Telecommunications Networks, 109 YALE L.J. 417, 462-64 (1999).

398. For a general discussion about real options, see Jerry A. Hausman, Gregory K. Leonard \& J. Gregory Sidak, Patent Damages and Real Options: How Judicial Characterization of Noninfringing Alternatives Reduces Incentives to Innovate, 22 BERKELEY TECH. L.J. 825 (2007). 
have the prerogative to refuse to receive the offer of a free option. As a matter of economic theory, while holding income constant, a consumer's utility cannot be increased by reducing from $n$ to $n-1$ the number of goods that she may consume. Moreover, in the case of mobile apps, the cost to the consumer of holding that option is essentially zero because the storage capacity of the consumer's mobile device is vast. There is no infringement of consumer sovereignty here, let alone one that rises to an antitrust concern.

Nonetheless, assume for the sake of argument that GMS constitutes a bundle of separate products and that Google has market power over the tying product, neither of which is self-evident from the allegation in the California class action litigation. The MADA's requirements still would not constitute unlawful tying under the Supreme Court's precedent, because the MADA's requirements do not harm consumers or the competitive process. The amended complaint incorrectly assumed that in the but-for world, Google would offer its apps free of charge. It disregards the fact that Google offers to manufacturers its GMS free of charge as compensation for choosing Google Search as the default search engine at certain access points on the device. ${ }^{399}$ In the absence of such selection, Google loses out on a fair chance to monetize its own apps, the development of which requires significant financial resources.

The MADA's requirements do not restrict competition among mobile operating systems, mobile apps, or in the mobile search market. To the contrary, by increasing Android's appeal, the MADA's requirements spur, rather than restrict, competition in the mobile OS market. Therefore, the MADA does not meet the third requirement of a tying practice: harm to competition.

Google's licensing practice yields procompetitive benefits for several stakeholders of the mobile device industry. The MADA's requirements enable Android to compete with other mobile operating systems. The increased competition among mobile platforms benefits consumers, manufacturers of mobile devices, app developers, and advertisers. Consumers benefit from the lower prices and higher quality of mobile devices. Manufacturers benefit from having cheaper and higher quality mobile operating systems. App developers benefit, because mobile platforms compete to attract app developers by offering more appealing conditions.

399. Google-Samsung MADA, supra note $325, \S \S 2.1,3.3,3.4$. 
Advertisers benefit from the large base of users generated by Android's appeal.

The Supreme Court's tying jurisprudence indicates that the MADA's requirements do not constitute anticompetitive tying. Even if contrary to fact Google's licensing practice were found to reduce competition, the MADA's requirements would still support the affirmative defense of an objective business justification because the MADA (1) creates welfareenhancing efficiencies for all the market participants and consumers, and (2) stimulates competition in the mobile OS market. This conclusion holds $a$ fortiori with respect to the rule of reason approach that the D.C. Circuit adopted in Microsoft III for software integration. An affirmative defense for software integration applies as much as, or more than, it would under the Supreme Court's traditional four-part rule for tying arrangements. A court applying the D.C. Circuit's rule for software integration would find the MADA lawful under the rule of reason.

\section{The Benefits to Consumers, Manufacturers of Mobile Devices, and App Developers from the MADA's Requirements}

The MADA's requirements do not benefit Google alone. They also create positive externalities for other stakeholders of the mobile device industry. The MADA's requirements benefit consumers both directly and indirectly by increasing the quality of the experience with Androidoperated devices that use GMS and by increasing competition in the market for mobile devices. ${ }^{400}$ At the same time, by maintaining the competitiveness of Android-operated devices that use GMS, the MADA's requirements benefit manufacturers and app developers. ${ }^{401}$

\section{Benefits to Consumers}

The MADA provides indirect benefits to the end user. By maintaining Android's appeal, the MADA stimulates competition in the market for mobile operating systems and, consequently, in the market for mobile devices. When Google introduced Android in 2007, various mobile operating systems were available. ${ }^{402}$ However, none could effectively

400. See infra text accompanying notes 403-09.

401. The MADA also benefits advertisers because Google Search "matches people who want to buy things to those who want to sell things." Varian, supra note 278, at 11. The large number of users that Google services can attract enables an advertiser to better target the consumers most likely to buy its product.

402. Industry Leaders Announce Open Platform for Mobile Devices, OPEN HANDSET ALLIANCE (Nov. 5, 2007), http://www.openhandsetalliance.com/press_110507.html [http://perma. cc/2PB5-ABQ2]. 
compete with Apple's iOS. Google created an alternative-a fresh OS available free of charge-which soon became a commercially viable alternative to iOS. With a free version of the Android OS, the reduced costs of manufacturing mobile devices enabled manufacturers to lower prices on mobile devices and compete effectively against Apple. Android's introduction generated the entry of lower-end smartphones into a market previously occupied solely by feature phones. ${ }^{403}$ The resulting competition in the mobile device market induced manufacturers - like Apple - to lower prices and increase the pace of innovation. ${ }^{404}$ By sustaining vigorous competition in the market for mobile operating systems, the MADA's requirements have indirectly benefited consumers by delivering lower prices and increased innovation in the market for mobile devices.

Implicit in the California class action complaint was an assumption that consumers tell producers how much integration of software for mobile devices is optimal. More generally, one might ask whether it is consumers or producers who decide, in the first instance, which goods producers shall supply. The class action complaint presumed that consumers make such decisions, and that their evident preference is for less rather than more product integration. ${ }^{405}$ There is, however, a strong argument to the contrary about the revelation of consumer demand. In 1921, the great University of Chicago price theorist Frank Knight argued that producers are better able than consumers to anticipate future consumer preferences. Knight posed the problem of revelation of consumer preferences as follows:

The essence of organized economic activity is the production by certain persons of goods which will be used to satisfy the wants of other persons. The first question which arises then is, which of these groups in any particular case,

403. Android Pushes Past 80\% Market Share While Windows Phone Shipments Leap 156.0\% Year over Year in the Third Quarter, MARKETWATCH (Nov. 12, 2013, 9:00 AM), http://www.marketwatch.com/story/android-pushes-past-80-market-share-while-windowsphone-shipments-leap-1560-year-over-year-in-the-third-quarter-according-to-idc-201311-12 [http://perma.cc/H4M6-Y3XN]

404. See, e.g., Tim Bradshaw, Apple Seeks To Fend Off Competition with Cheaper $8 G b$ iPhone $5 c$, FIN. TIMES (Mar. 18, 2014, 3:18 PM), http://www.ft.com/intl $/ \mathrm{cms} / \mathrm{s} / 0 /$ 82e1f004-aea9-11e3-8e41-00144feab7de.html\#axzz3BAmfhbnN [http://perma.cc/3874EQF9]; David Goldman, Apple's Profit Problem, CNN MonEy (Apr. 24, 2013, 12:32 PM), http://money.cnn.com/2013/04/24/technology/apple-profit-margin/ [http://perma.cc/SZA5QQBY]; Trefis Team, Android Pressures Apple on iPhone Pricing, ForBEs (Apr. 28, 2011, 3:31 PM), http://www.forbes.com/sites/greatspeculations/2011/04/28/android-pressuresapple-on-iphone-pricing/ [http://perma.cc/JYB7-U4VY].

405. Class Action Complaint, supra note 13, at 29. 
producers or consumers, shall do the foreseeing as to the future wants to be satisfied. 406

Knight did not believe that consumers specify their preferences clearly to producers. Rather, he reasoned:

At first sight it would appear that the consumer should be in a better position to anticipate his own wants than the producer to anticipate them for him, but we notice at once that this is not what takes place. The primary phase of economic organization is the production of goods for a general market, not upon direct order of the consumer. 407

Henry Ford is reputed to have said more simply, "If I had asked people what they wanted, they would have said faster horses."

When one considers Knight's insight in the context of a tying rule for mobile apps, it becomes increasingly clear that it would harm consumer welfare for a court to mandate that Google may offer the free suite of GMS apps only if it allows other firms in the vertical chain of production to disaggregate the suite or select Google mobile apps on an à la carte basis. To require Google to do so would thwart its role as the party who facilitates the revelation of consumer preferences. It is reasonable to expect that the importance of this revelation of preferences increases with the extent of technological dynamism in a particular product market.

When competition exists for the market in a Schumpeterian sense, consumer welfare will depend to a greater extent on rivalry with respect to nonprice variables, such as quality and innovation. ${ }^{409}$ Competition for the market is a contest to define entirely new demand curves or to push existing demand curves outward with vastly improved combinations of price and performance. Jefferson Parish's analysis of the "character of demand" is uninformative when consumers face products for which they have newfound and uncertain demand. The revelation of consumer preferences is a genuine innovation or discovery, one whose value courts and antitrust officials can belittle or ignore only at great peril to consumer welfare.

\section{Benefits to Manufacturers of Mobile Devices}

The MADA's requirements benefit manufacturers of mobile devices. Before Android's release, a mobile device manufacturer needed either to

406. Frank KNight, Risk, UnCERTAINTy AND Profit 240 (Harper \& Row 1965)

(1921).

407. Id.

408. See My Customers Would Have Asked for a Faster Horse, QUOTE INVESTIGATOR http://quoteinvestigator.com/2011/07/28/ford-faster-horse/ [http://perma.cc/9XP4-DYA9] (last visited Aug. 11, 2015).

409. See Richard Schmalensee, Antitrust Issues in Schumpeterian Industries, 90 AM. ECON. ReV. (PAPERS \& PROC.) 192, 192 (2000). 
pay a license fee or to incur the cost of developing its own OS and a mobile suite of apps. Both options were relatively costly. ${ }^{410}$ The MADA provided the manufacturer an alternative option: the ability to obtain both the OS and GMS free of charge in exchange for promoting Google's services. ${ }^{411}$ The MADA thus enabled the manufacturer to compete effectively with vertically integrated mobile device manufacturers, like Apple and Blackberry without developing its own OS and mobile suite. Samsung's experience in the market for mobile devices illustrates the positive effects that a MADA can have for a manufacturer. Samsung began producing Android phones - including GMS - in 2009, when its smartphone market share was only 1.8 percent. ${ }^{412}$ By June 2013, Samsung's market share had risen to 27.7 percent. ${ }^{413}$ Although other factors surely contributed to Samsung's success, its ability to obtain Android and GMS free of charge improved the competitiveness of the company's mobile devices.

The MADA does not restrict a manufacturer's choice of OS or mobile apps. ${ }^{414}$ As explained, the manufacturer's use of Android is not conditional on its acceptance of the MADA's requirements. ${ }^{415}$ A manufacturer is free to use Android OS without GMS preloaded. Furthermore, even when a manufacturer decides to preload GMS, the MADA does not exclude the manufacturer from adopting other operating systems on its other devices, because the MADA applies per device and not per platform or product model. ${ }^{416}$ A manufacturer that enters into a MADA can "multi-home"that is, the manufacturer can offer, besides Android-operated devices,

410. For example, as of 2008, Microsoft charged manufacturers $\$ 8$ to $\$ 15$ per device for its Windows Mobile OS. Dave Rosenberg, Windows Mobile Licensing Fees To Remain Intact, CNET (Oct. 1, 2008, 5:18 AM), http://www.cnet.com/news/windows-mobilelicensing-fees-to-remain-intact/ [http://perma.cc/AND9-FC3L].

411. Google-Samsung MADA, supra note $325, \S 2.1$.

412. Gartner Says Worldwide Smartphone Sales Reached Its Lowest Growth Rate with 3.7 Per Cent Increase in Fourth Quarter of 2008, GARTNER (Mar. 11, 2009), http:// www.gartner.com/newsroom/id/910112 [http://perma.cc/7GZ6-ZGB8]; Sascha Segan, Samsung Announces First Android Phone, PCMAG.COM (Apr. 27, 2009, 11:00 AM), http://www.pcmag.com/article2/0,2817,2345968,00.asp [http://perma.cc/3Q4B-ERKB].

413. Josh Beckerman, Apple Keeps U.S. Smartphone Market-Share Lead, but Samsung Gains Ground, WALL ST. J. (June 3, 2014, 5:18 PM), http://online.wsj.com/ articles/apple-maintains-u-s-smartphone-market-share-lead-but-samsung-gains-groundcomscore-reports-1401830291 [http://perma.cc/M6J8-YS97].

414. Google-Samsung MADA, supra note 325, § 2.4

415. Id. $\$ 2.7$.

416. Id. $\S 2.4$ ("Company has no obligation to install the Google Applications on all of its devices."). 
devices that rely on other operating systems. For example, HTC offers phones running on Android and on Windows Phone. ${ }^{417}$ Thus, the MADA does not prevent a manufacturer that wishes to offer Android-operated devices preloaded with GMS from simultaneously offering devices that run on another OS.

Although the MADA imposes placement requirements on the distribution of GMS, the required configuration does not impair a manufacturer's ability to customize the device by preloading other apps. ${ }^{418}$ A manufacturer remains free to preload its own apps and third-party apps and place them on the home screen, differentiating its devices from others available in the market. ${ }^{419}$ For example, Samsung's out of the box mobile devices come with Samsung's own apps on the default home screen, such as Samsung Apps-Samsung's proprietary mobile app store. ${ }^{420}$ A manufacturer might also preload third-party apps. For example, HTC preloads its phones with the Dropbox app. ${ }^{421}$ The MADA does not prevent the manufacturer from placing those apps in the uppermost location on the mobile device screen. Hence, manufacturers are free to preload non-Google apps on their devices and place those apps next to Google apps.

Moreover, carriers have discretion in selecting the apps that are preloaded on a mobile device. ${ }^{422}$ Carriers can, and often do, require the manufacturer to preload carrier-specific apps on the mobile device. ${ }^{423}$ Carriers can also

417. See Smartphones, HTC, http://www.htc.com/us/smartphones [http://perma.cc/ FYK4-SA4B] (last visited Mar, 16, 2015).

418. Google-Samsung MADA, supra note $325, \S 3.4$

419. See, e.g., App Install Solutions for the World's Top Device Manufacturers, SwEETLABS, http://sweetlabs.com/device-manufacturers [http://perma.cc/E6BJ-REFJ] (last visited Aug. 11, 2015); Antone Gonsalves, Android Smartphone Makers Are Throwing You Under the Bus, COMPUTERWORLD (Nov. 6, 2013, 10:11 AM), http://www.computer world.com/article/2475389/mobile-security/android-smartphone-makers-are-throwing-youunder-the-bus.html [http://perma.cc/273C-BQ9Z].

420. See, e.g., Steve Litchfield, Review: Samsung Galaxy S4, ANDroid BEAT (May 18, 2013), http://www.androidbeat.com/2013/05/review-samsung-galaxy-s4/ [http://perma.cc/ 2N3J-XALE]

421. HTC Preloads Dropbox on All New Phones To Trump iCloud, MACNN (Oct. 24, 2011, 4:20 PM), http://www.macnn.com/articles/11/10/24/htc.goes.beyond.rhyme.with.drop box.plans/ [http://perma.cc/A25U-N9L3].

422. See, e.g., Tim Kridel, Cracking the Carrier and Vendor Market, DigiTAL INNOVATION GAZETTE, http://www.digitalinnovationgazette.com/blog/app_distribution_ vendor_preload/\#axzz33nw4YkCX [http://perma.cc/GBQ7-3XPP] (last visited Aug. 11, 2015) ("[H]andset manufacturers don't control what ultimately remains on the phone. An operator may decide to wipe the phone clean of everything except those apps that specifically fit their goals . . .."); Mossberg, supra note 292.

423. See, e.g., How Verizon Preloaded Apps Make Life More Convenient, Verizon, $\mathrm{http}: / / \mathrm{www}$.verizonwireless.com/insiders-guide/network-and-plans/how-verizon-preloadedapps-make-life-more-convenient/ [http://perma.cc/8XBW-29YK] (last visited Aug. 11, 2015). 
require the manufacturer to install third-party apps, along with GMS. ${ }^{424}$ Carriers might restrict the location of those apps on the screen of the mobile device.

In sum, a manufacturer using Android is free to decide whether to preload GMS or not. Even when the manufacturer decides to preload GMS, the MADA does not limit the manufacturer's ability to preload its own apps or third-party apps on the mobile device and place those apps next to Google's apps. Both the manufacturer and the carrier have an important role in determining how mobile apps will ultimately appear on the device.

\section{Benefits to App Developers}

The MADA benefits app developers. By promoting Android's competitiveness, the MADA fosters the viability of an open distribution platform that app developers and online service providers can use as an alternative to proprietary operating systems. Android's success stimulated competition among mobile platforms to attract app developers. As explained in Part III.B, before the introduction of Android-operated devices, few mobile apps were available. ${ }^{425}$ Apple provided third-party developers with only a limited opportunity to develop mobile apps. ${ }^{426}$ Similarly, carriers limited the role of third-party developers. ${ }^{427}$ However, the success of Androidoperated devices has helped change this situation by providing third parties greater freedom and a better platform for the development of mobile apps. As a result, a market for mobile apps has arisen, and apps have become a crucial component of mobile devices. ${ }^{428}$ As noted earlier, app developers

424. See, e.g., Kevin Fitchard, Uber Gets Cozy with AT\&T, Using Its Network and Preloading Its App on Android Phones, Gigaom (May 28, 2014, 3:12 PM), https:// gigaom.com/2014/05/28/uber-gets-cozy-with-att-using-its-network-and-preloading-its-appon-android-phones [https://perma.cc/R2F5-QR5M]; Cosmin Vasile, T-Mobile Android Devices Now Preloaded with Lookout Security App, SOFTPEDIA (Oct. 25, 2012, 5:01 PM), http://news.softpedia.com/news/T-Mobile-Android-Devices-Now-Preloaded-with-LookoutSecurity-App-302194.shtml [http://perma.cc/TKH7-Z6F8].

425. See supra Part III.B.

426. See Chris Ziegler, Apple's iPhone Lockdown: Apps Must Be Written in One of Three Languages, Adobe in the Hurt Locker, ENDGADGET (Apr. 8, 2010, 10:59 PM), http://www.engadget.com/2010/04/08/apples-iphone-lockdown-apps-must-be-written-inone-of-three-la/ [http://perma.cc/NYY2-XC85].

427. See, e.g., ITU Milestone, supra note 312 (discussing the restrictions that carriers place on app development).

428. See, e.g., Danny Crichton, As Mobile Roars Ahead, It's Time to Finally Admit the Web Is Dying, TECHCRUNCH (May 9, 2014), http://techcrunch.com/2014/05/09/as-mobileroars-ahead-its-time-to-finally-admit-the-world-wide-web-is-dying/ http://perma.cc/8QXV- 
have an incentive to invest resources to develop apps for a platform when there is some assurance of compatibility across devices. The MADA creates incentives for OEMs to develop compatible devices. There is now robust competition among providers of operating systems, such as Apple and Google, to attract app developers to their respective platforms. Each company strives to make its app development kits more powerful and accessible to app developers. ${ }^{429}$ The result is greater competition among providers of mobile operating systems for app developers. Competition among app developers also increases the quality of apps and thus enhances the consumer experience.

The MADA's requirements do not foreclose competing apps. Manufacturers and carriers are free to preload other apps on mobile devices. ${ }^{430}$ However, one might argue that preferential placement for Google apps and the bundling of apps within GMS limit the ability of competitors to challenge Google's apps. This argument is not persuasive for two reasons.

First, Google does not have an incentive to harm competition in the market for mobile apps. Google offers products to consumers at a price of zero because those consumers will generate revenue for Google through the use of these apps. ${ }^{431}$ Use of Google apps by consumers is necessary for Google to remain profitable. Popular mobile apps have positive externalities; the availability of mobile apps will often enhance the attractiveness of a mobile device to consumers. The more attractive the apps available on a mobile device, the higher the expected demand for that particular device. In other words, Google has a clear interest in allowing third parties to develop and offer apps that attract a large number of users to Android-operated devices. Google consequently has no incentive to foreclose competitors from the app market. ${ }^{432}$

2NXN]; Ralf-Godron Jahns, 6 Reasons why Mobile Apps Will Become as Important for Companies as Corporate Websites, RESEARCH2GUIDANCE (May 17, 2010), http://research2 guidance.com/corporate-app-will-become-as-important-for-companies-as-having-acorporate-website-a-look-at-the-german-market/ [http://perma.cc/3U78-VXMA].

429. For example, in June 2014, Apple introduced Swift, a new programming language for iOS applications, which makes it easier to develop applications for iOS devices. Apple Opens iOS to Third-Party Dev Tools, Reveals Approval Guidelines, APPLEINSIDER (Sept. 9, 2010, 5:35 AM), http://appleinsider.com/articles/10/09/09/apple_no_longer_ banning_third_party_ios_development_tools [http://perma.cc/YEC7-Y7KN]; Sascha Segan, Apple's Swift Language: A Really Big Deal, PCMAG.COM (June 3, 2014, 6:28 PM), http:// www.pcmag.com/article2/0,2817,2458939,00.asp [http://perma.cc/K2J8-K22Q].

430. See supra Part VII.C.2.

431. Kenney \& Pon, supra note 281, at 253.

432. The importance of a robust mobile apps market increases as a larger portion of the population turns toward mobile access to the internet. See MAEve DugGan \& AAron Smith, Pew Research Ctr., Cell Internet Use 2013, at 2 (2013), http://www.pew internet.org/files/old-media//Files/Reports/2013/PIP_CellInternetUse2013.pdf [http://perma. cc/JU2B-ADHP] (reporting that thirty-four percent of mobile internet users go online 
Second, even if one assumed, contrary to fact, that Google wanted to harm competition in the app market, the MADA's requirements would not enable Google to do so. The primary criticisms of Google's MADA with respect to the app market are, first, that it offers its apps combined in a suite, and, second, that it requires that certain apps be placed on or near the home screen. Neither practice harms competition.

On an Android-operated device preloaded with GMS, a user can easily download additional apps besides those that are part of GMS. Google itself informs a consumer how to download apps and digital content to the consumer's device using the Google Play Store app or the consumer's computer. ${ }^{433}$ The average smartphone user downloads about twenty-five apps per device, which confirms that consumers are familiar with the process of downloading apps. ${ }^{434}$ Further, a mobile device has enough storage capacity for additional apps, even if it comes with preloaded apps. The available storage on a mobile device out of the box ultimately depends on its customization by the manufacturer or carrier, which may preload other apps and features. For example, the Google Nexus 516 GB, an Android phone, has $12.28 \mathrm{~GB}$ of usable storage space, and the HTC Mini 16 GB has 10.44 GB of usable storage space. ${ }^{435}$ If one assumes that the average size of each individual Google app is $20 \mathrm{MB}$ - which significantly exceeds the average app size - then GMS consumes only $0.18 \mathrm{~GB}$ of storage. ${ }^{436}$ Moreover, a consumer can purchase a device with

mostly using their cellphones); KATHRYN ZiCKUHR \& AARON SMith, PEW RESEARCH CTR., HOME BROADBAND 2013, at 4 (2013), http://www.pewinternet.org/2013/08/26/homebroadband-2013/ [http://perma.cc/LKZ8-HDRZ] (reporting that ten percent of Americans indicate that they do not have a broadband connection at home but that they do own a smartphone).

433. See Install or Purchase Apps \& Digital Content, GoogLe, https://support.google. com/googleplay/answer/113409?hl=en\&ref_topic=3365058 [https://perma.cc/NL3B-2DER] (last visited Aug. 11, 2015).

434. Zoe Fox, The Average Smartphone User Downloads 25 Apps, MASHABLE (Sept. 5, 2013), http://mashable.com/2013/09/05/most-apps-download-countries/ [http://perma.cc/ CXJ9-5UCY]; Michael H., The Average Global Smartphone User Has Downloaded 26 Apps, PHONEARENA.COM (Sept. 6, 2013, 12:28 AM), http://www.phonearena.com/news/ The-average-global-smartphone-user-has-downloaded-26-apps_id47160 [http://perma.cc/ L96L-26KG].

435. Jon Barrow, Phone Storage Compared-Samsung S4 Still in Last Place, WHICH? (Jan. 22, 2014), http://blogs.which.co.uk/technology/phones-3/phone-storage-comparedsamsung-s4-still-in-last-place/ [http://perma.cc/2QAQ-J3MN].

436. See, e.g., Android Applications: What Is the Size of an Average Android App?, QuORA (Aug. 5, 2013), http://www.quora.com/Android-Applications/What-is-the-sizeof-an-average-Android-app [http://perma.cc/B7XJ-GUD9]. 
a higher or lower storage capacity depending on how many apps the user plans to store on the device. Therefore, the preloaded GMS takes only a small fraction of the device's storage capacity, leaving ample storage space for the download of other apps.

Moreover, like Google, third-party app developers can negotiate with a manufacturer for the preferential placement of their apps on the screen of the mobile device. ${ }^{437}$ Third-party app developers can achieve a comparable agreement with the manufacturer or carrier. Furthermore, a third-party app developer can educate consumers. For example, an app developer can instruct a user during installation on how best to access the app from the home screen, or the app developer can highlight the app's main features to indicate its usefulness over the preinstalled apps in GMS. ${ }^{438}$ In short, a MADA does not prevent third-party apps from obtaining a screen placement comparable to the one that Google has negotiated.

Contrary to the argument that the preload of GMS discourages competitors from paying for the preinstallment of their apps, evidence shows that third parties can negotiate with manufacturers or carriers to secure a prominent position for their apps. For example, Facebook has negotiated a primary position of its mobile app on several devices. ${ }^{439}$ The MADA's requirements do not prevent third-party app developers from negotiating conditions similar to those that Google negotiates within the MADA.

Finally, a third-party app developer can also offer its apps through high quality HTML5, the fifth generation of HyperText Markup Language. ${ }^{440}$ HTML5 web apps are directly accessible to users through the Internet browser, as opposed to native apps that are written for a specific OS to run

437. See supra Part VII.C.2.

438. See, e.g., Matt, Add Us to Your Homescreen on Your iOS Device, ARCADE ON (May 13, 2013), http://arcade-on.com/news/add-us-to-your-homescreen-on-your-ios-device/ [http://perma.cc/MG7G-REPT].

439. Josh Constine, ISA 2011: Sony Ericsson To Preload Its Android Devices with Facebook Login at Startup, SOCIALTIMES (Jan. 25, 2011, 3:59 PM), http://www.adweek. com/socialtimes/sony-ericsson-preload-facebook/255759? red=if [http://perma.cc/J5AHPDA3]; Bogdan Petrovan, Facebook Wants to Take Over the Android Homescreen; More Manufacturers Incoming, ANDROID AUTHORITY (Mar. 29, 2013), http://www.android authority.com/facebook-phone-homescreen-181268/ [http://perma.cc/92G2-UF4P] Chris Velazco, Meet the HTC First, The First Android Phone To Come Preloaded with Facebook Home, TECHCRUNCH (Apr. 4, 2013), http://techcrunch.com/2013/04/04/meet-the-htc-firstthe-first-android-smartphone-to-come-preloaded-with-facebook-home/ [http://perma.cc/PGR877PE].

440. See Steve Lohr, In a New Web World, No Application Is an Island, N.Y. TIMES (Mar. 26, 2011), http://www.nytimes.com/2011/03/27/business/27unboxed.html?_r=2\& [http://perma.cc/93J4-4WFU]; Matt Marshall, How HTML5 Will Kill the Native App, VENTURE BEAT (Apr. 7, 2011, 11:52 AM), http://venturebeat.com/2011/04/07/how-html5will-kill-the-native-app/ [http://perma.cc/S78A-4LCW]. 
on a device. ${ }^{441}$ Some expect that, with "constantly improving integration with built-in mobile features" and the option of creating a "hybrid app" that can be used across operating systems, ${ }^{442}$ HTML5 web apps-and newer versions of web apps - will displace native apps. ${ }^{443}$ Additionally, a consumer can place a shortcut icon on her home screen to easily access these web-based apps. ${ }^{444}$ Thus, a third-party developer can also offer a user the ability to access apps through his Internet browser, instead of downloading the app on to his device.

In sum, a manufacturer's decision to preload GMS does not plausibly harm app developers. Consumers can easily download third-party apps and manage their placement on the device's screen as they prefer. At the same time, if a third-party app developer believes that the placement of its app on the device's screen is essential to attracting the end user's attention, the app developer can negotiate with the manufacturer for premium placement of its apps on the device's screen.

\section{CONCLUSION}

In 2008, the first Android-operated device came to market. ${ }^{445}$ Google's strategy has been to offer its mobile OS and mobile apps free of charge so as to attract a large user base. ${ }^{446}$ Economic analysis of Google's business model and the characteristics of the mobile device industry confirm that Google has valid business justifications for offering GMS under the conditions specified in the MADA. Until the launch of Android, carriers and platform owners controlled access to the mobile device business. With Android, Google provided an alternative mobile distribution platform, which enabled app developers and online service providers-including Google - to distribute their apps and services outside the walled gardens

441. Lohr, supra note 440.

442. See Ryan Matzner, Why Web Apps Will Crush Native Apps, Mashable (Sept. 12, 2012, 4:52 PM), http://mashable.com/2012/09/12/web-vs-native-apps/ [http://perma.cc/ BSS4-634E].

443. Aidan Quilligan, HTML5 vs. Native Mobile Apps: Myths and Misconceptions, FORBES (Jan. 23, 2013, 7:55 PM), http://www.forbes.com/sites/ciocentral/2013/01/23/html5 -vs-native-mobile-apps-myths-and-misconceptions/ [http://perma.cc/AT4C-2V2J]; Matzner, supra note 442.

444. Brian Williams, Add a Web Shortcut to Android Home Screen, Ask YouR ANDROID (Nov. 29, 2011, 7:13 AM), http://www.askyourandroid.com/android-news/adda-web-shortcut-to-android-home-screen/ [http://perma.cc/9LDW-NWHL].

445. See supra p. 620.

446. See supra Part VI.B.1. 
of proprietary operating systems. In a world of closed platforms, Google faced the risk that users could be cut off from accessing Google's apps and mobile services. In contrast, an open platform would permit Google - and other app developers and online service providers - to monetize their offerings according to their individual business models. The development of the Android OS as an alternative mobile platform was thus an important element in Google's aim to foster its presence in the mobile device business.

The Supreme Court recognizes that tying arrangements often promote competition and benefit consumers. ${ }^{447}$ Under the Court's four-part test, Google's combined offering of the apps in GMS is clearly lawful. Google lacks market power in the functions provided by GMS. Because the apps are provided free of charge, one cannot meaningfully argue that offering Google apps as part of the GMS suite forces consumers to pay for services they do not want. Google's free suite of apps benefits both competition and consumers. The D.C. Circuit's rule of reason analysis of software integration specifically recognizes that antitrust law should not discourage innovations, including the integration of multiple functionalities into one product.

Although EU competition rules differ from those applied in the United States, the MADA's welfare-increasing effects on consumers are the same on both sides of the Atlantic. The MADA's requirements help Google to promote Android's competitiveness. ${ }^{448}$ They improve the consumer experience by reducing the risk of fragmentation of the Android OS. The MADA's requirements enable Android-operated devices that include GMS to meet consumer expectations by offering an out of the box experience comparable to that offered by devices that rely on closed or proprietary operating systems. And the MADA's requirements enable Google to avoid free riding and cherry-picking, preventing third parties from appropriating the economic value of the users that Google attracts by distributing free services. The MADA thus ensures that Google maintains sufficient incentives to invest in innovation and provide its services free of charge.

Far from harming the competitive process, Google's practice of giving away the Android OS and the entire Google Mobile Services suite for free-and requiring that when manufacturers choose to preload GMS on their mobile devices, they pass along the complete suite of apps in GMS to consumers - has benefited manufacturers of mobile devices and app developers. It has invigorated competition among mobile platforms and mobile devices. Google's distribution of free mobile apps in GMS has produced a market success, not a market failure.

447. See supra Part IV.

448. See supra Part VI.D. 